\title{
Kişisel Mektuplarının Açılması Meselesiyle Meclis-i Mebusan Gündemine Gelen Bayezid Mebusu Süleyman Sûdî (Acarbay) Bey'in Siyasi Faaliyetleri
}

\section{Political Activities of Bayezid Deputy Süleyman Sudi (Acarbay) Bey Who Was Put on The Agenda of Chamber of Deputies Concerning the Investigation of His Personal Correspondence}

\author{
Prof. Dr. Şaban ORTAK ${ }^{(D)} 1$
}

\begin{abstract}
$\ddot{O} \mathbf{z}$
1866 yılında Bayezit'te doğan Süleyman Sûdî Bey, Tutak Aşar ve Ağnam Memuru Kapılar Kethüdâsızâde Abdülkadir Ağa'nın oğludur. İlk ve ortaöğrenimini Bayezit'te tamamlayan Süleyman Sûdî Bey ayrıca medrese eğitimi de almıştır. 1883 yılında Karakilise Mahkemesi'nde kâtiplik görevine başlayan Süleyman Sûdî Bey, 1887'de Tutak Bidayet Mahkemesi birinci katipliğine atanmışsa da 1892 yılında Eleşkird Bidayet Mahkemesi katipliğine nakledilmiştir. 1904 yılında bu görevden azledilen Süleyman Sûdî Bey, aynı yıl tekrar Tutak Bidayet Mahkemesi katipliğine atanmıştır. II. Meşrutiyet'in ilanından sonra yapılan seçimlerde 16 Ocak 1909 tarihinde Bayezit Mebusu seçilen Süleyman Sûdî Bey, ikinci dönem Meclis-i Mebusan'da da aynı görevine devam etmiştir. 23 Temmuz 1912'de Meclisin feshi ile mebusluk görevi sona eren Süleyman Sûdî Bey'in 1912-1918 yılları arasındaki faaliyetleri hakkında fazla bilgi bulunmamaktadır.
\end{abstract}

1918 y1lında Mondros Mütarekesi sonrasında başlayan Millî Mücadeleye katılan Süleyman Sûdî Bey, Birinci TBMM'ne Bayezit Mebusu olarak seçilmiş ve 15 Mayıs 1920'de Meclise katılmıştır. Mecliste Dâhiliye (İçişleri) ve Dilekçe Encümenleri ile Memurin Muhakemâtı Tetkik Kurulu'nda görev alan Süleyman Sûdî Bey ayrıca işgalden kurtarılan bölgeler muhacirleri için komisyonda çalışmıştır. Bu dönemde 3 kanun önergesi ve 4 soru önergesi veren Süleyman Sûdî Bey, 1'i gizli oturumda olmak üzere Meclis'te 12 kez konuşma yapmıștır. 1923 yılında yapılan II. TBMM seçimlerinde yine Bayezit Mebusu seçilen Süleyman Sûdî Bey bu dönemde; 1 kanun teklifi, 3 önerge vermiş ve 9 konuşma yapmıştır. 7 Ocak 1928 tarihinde Bayezit'te vefat eden Süleyman Sûdî Bey'in ailesi “Acarbay” soyadını almıştır.

Süleyman Sûdî Bey'in Meclisteki faaliyetleri arasında; Bayezit Livası'ın müstakil liva (bağımsız sancak) olarak idaresi için 1920 yılında verdiği kanun teklifinin TBMM tarafından kabul edilmesi ve yasalaşması önemlidir. Süleyman Sûdî Bey'in bir başka teklifi; 1924 yılında Karaköse Kaza merkezinde Gazi Mustafa Kemal Paşa'nın ismi ile bir idadi açılmasına dairdir. Bu teklif TBMM Maarif Encümeni'nde görüşülürken Maarif Vekili İsmail Safa Bey de toplantıya katılmıştır. Bu toplantıda; Karaköse'de idadiye talebe yetiştirecek yeteri kadar iptidai mektep bulunmadığı gerekçesiyle bu teklif kabul görmemiş, ancak 1924 yılında Doğu Anadolu'da 10 tane yatılı iptidai mektep açılması planlandığı için bu teklifin Maarif Vekaleti'ne havale edilmesi kararlaştırılmıştır. Bayezit'in yetiştirdiği önemli siyasi şahsiyetlerden birisi olan Süleyman Sûdî Bey, memuriyetlerinin yanında hem Meclis-i Mebusan'da ve hem de TBMM'nde ikişer dönem mebusluk görevinde bulunmuştur. Bu görevleri sırasında gerek yerel ve gerekse ülke genelini ilgilendiren konularla ilgili olarak yasama faaliyetlerinde bulunmuştur.

\footnotetext{
${ }^{1}$ Afyon Kocatepe Üniversitesi, Eğitim Fakültesi, sortak@aku.edu.tr.

Atıf için (to cite): Ortak, Ş. (2020). Kişisel mektuplarının açılması meselesiyle Meclis-i Mebusan gündemine gelen Bayezid Mebusu Süleyman Sûdî (Acarbay) Bey'in siyasi faaliyetleri. Afyon Kocatepe Üniversitesi Sosyal Bilimler Dergisi, 22(TBMM'nin 100. Y1lı ve Millî İrade Özel Sayısı), 44-68.
} 
Anahtar Kelimeler: Bayezit Sancağı, Süleyman Sûdî Bey, Meclis-i Mebusan, kişisel mektupların açılması, Türkiye Büyük Millet Meclisi

Makale Türü: Araştırma

\begin{abstract}
Süleyman Sûdî Bey, born in 1866, was the son of Abdülkadir Ağa. He completed his elementary and secondary education in Bayezit, and then, he took lectures in madrasah. Süleyman Sûdî Bey, who began his carrier as a clerk in the court of Karakilise, appointed to the first secretary of Court of First Instance of Tutak in 1887. Then, he was transferred to the secretary of Court of First Instance of Eleşkird in 1892. In 1904 , he was dismissed from this duty, and appointed back to the first secretary in Tutak. As the result of elections held on January 9th, 1909, after the promulgation of the second constitutional era, he was elected as the deputy of Bayezit sanjak; and he continued this service in the second term as well. Few details are known about life of Süleyman Sûdî Bey, whose deputyship expired due to the annulment of the parliament on July 23rd, 1912.

He was elected as Bayezit representative to the first Grand National Assembly during the National Struggle began after the Armistice of Mudros in 1918, and he joined to the assembly on May 15th, 1920. In his service in the assembly, he served in the Committee of Internal Affairs (Dahiliye Encümeni) and Committee on Petitions (Dilekçe Encümeni), and in the Board of Review for Examination of Government Employees (Memurin Muhakematı Tetkik Kurulu). He also worked for the commission set up for refugees from liberated areas. During this period, Süleyman Sûdî Bey tabled four motions for parliamentary question, and introduced three bills for law drafts. He also made twelve speeches in the parliament, including one speech in a secret session. Süleyman Sûdî Bey, who was elected as Bayezit representative to the second Grand National Assembly in 1923; introduced one law draft and tabled a motion and made nine speeches in the parliament. He deceased on January 7th, 1928 in Bayezit, and his family took "Acarbay" surname.

Within his services in the assembly, his proposal for law draft in 1920, which was enacted, on administration of Bayezit as independent sanjak (müstakil sancak) is notable. Another proposal of Süleyman Sûdî Bey was opening of a high school by the name of Mustafa Kemal Pasha in the downtown of Karaköse district. Minister of Education İsmail Safa Bey attended the meeting on Süleyman Sûdî Bey's proposal in Committee of Education in the parliament. In this meeting, the proposal was refused due to the inadequacy of elementary education institutions in the area to raise sufficient number of students to the secondary education. Yet, in the same year, the decision to facilitate ten elementary boarding schools in Eastern Anatolia was taken; and his proposed project was transferred to the Ministry of Education. As one of the notable characters raised in Bayezit, Süleyman Sûdî Bey, along with his official duties, served as a deputy both in the Chamber of Deputies and in the Grand National Assembly, for two terms in each. During his service, he participated in legislative activities on national matters, as well as local issues.
\end{abstract}

Keywords: Bayezit Sanjak, Süleyman Sûdî Bey, opening personal letters, Chamber of Deputies, Grand National Assembly of Turkey

Paper Type: Research 


\section{Giriş}

Doksan Üç Harbi sırasında bir dönem Rusların eline düșen Bayezit Sancağı, işgalden kurtarıldıktan sonra Erzurum Vilayeti'ne bağlı olarak yönetilmeye devam etmiştir. Sınırda bulunması nedeniyle birçok tehlikeyi yakından hisseden bu sancak, aynı zamanda yükselmekte olan Ermeni şiddetiyle de karşı karşıya kalmıştır. Bir taraftan da aşiretler arası anlaşmazlıkların eksik olmadığı bir bölge olan Bayezit Sancağı'nın idaresinin kolaylaşması açısından müstakil sancak olması için bazı girişimler yapıldıysa da başarılı olamamıştır. Bunun sağlanması için ön ayak olanlardan birisi de II. Meşrutiyet Dönemi'nde Meclis-i Mebusan'da, I. ve II. TBMM'nde Bayezit'i temsil eden mebuslardan Süleyman Sûdî Bey'dir. Bu makalede, Süleyman Sûdî Bey'in biyografisi, memuriyet hayatı ve mebusluk görevleri sırasındaki faaliyetleri ele alınacaktır.

\section{Süleyman Sûdî Bey'in Hayatı}

Tutak Aşar ve Ağnam Memuru Kapılar Ketnüdâsızâde Abdülkadir Ağa ve Hatice Hanım'ın oğlu olan Süleyman Sûdî Bey, 1866 yılında (Hicri 1282, Rumi 1281) Bayezit Kasabası'nda doğdu. Bayezit Rüşdiyesi'nde öğrenim gören ve derslerini tamamlayan Süleyman Sûdî Bey, Şehadetnâme almaksızın okuldan ayrılmıştır. Özel hocalardan ve medresede tahsiline devam etmiştir. Tercüme-i Hâl varakasında Türkçe okuyup yazabildiği, Kürtçe, Ermenice ve Farsça dillerini bildiği belirtilmektedir. 21 Temmuz 1880* tarihinde Bayezit Sancağ Bidayet Mahkemesi Kâtipliğinde mülâzım (memur adayı, stajyer) olarak göreve başlayan Süleyman Sûdî Bey, 29 Aralık 1883 tarihinde 225 kuruş maaşla Karakilise Kazası Bidayet Mahkemesi İkinci Kâtip olarak tayin edilmiştir. 17 Ağustos 1887 'de terfi ettirilerek 400 kuruş maaşla Tutak ${ }^{2}$ Kazası Bidayet Mahkemesi Birinci Kâtipliğine atanan Süleyman Sûdî Bey, 21 Ocak 1893'te Eleşkird Kazası Bidayet Mahkemesi Birinci Kâtipliğine tayin edilmiştir. Bu görevi sırasında 31 Aralık 1898 tarihinde ek görev olarak Eleşkird Kazası Rüşdiye Mektebi Hüsn-i Hatt (Güzel Yazı) Muallimliğine atanan Süleyman Sûdî Bey hakkında şikâyetlerin devam etmesi üzerine açılan soruşturma dolayısıyla görevinden azledilmiştir (13 Mart 1901). Yapılan tahkikat neticesinde sûi hâli tespit edilemediğinden hakkında işlem yapılmasına gerek olmadığı Umûr-1 İ́crâ'iye Müdüriyeti'nce belirtilmesinden dolayı aynı göreve (Eleşkird Bidayet Mahkemesi Birinci Kâtipliğine) yeniden atanmıştır (24 Ağustos 1902). 16 Mart 1904'te Tutak Bidayet Mahkemesi Birinci Kâtipliğine tayin edilen Süleyman Sûdî Bey, usulsüzlük iddiası nedeniyle görevinden alınarak hakkında soruşturma açılmış ve yargılanmıştır. Yapılan yargılama neticesinde beraat eden Süleyman Sûdî Bey eski görevi olan Eleşkird Kazası Bidayet Mahkemesi Başkâtipliğine tayin edilmiştir. Bu görevi sırasında Kemal Ağa ile Derviş Ağa arasındaki arazi anlaşmazlığını keşif için görevlendirilen komisyona üye olarak katılan Süleyman Sûdî Bey hakkında ileri sürülen yeni bir iddia nedeniyle yeniden yargılanmışsa da suç unsuru bulunamadığından beraat etmiştir. $\mathrm{Bu}$ sırada II. Meşrutiyet'in ilanı sonrasında yapılan seçimde Bayezit Sancağı Mebusluğuna seçilen Süleyman Sûdî Bey, 16 Ocak 1909'da mazbatasını almış ve 18 Mart 1909 tarihinde Meclis-i Mebusan'a katılmıştır³.

\footnotetext{
* Süleyman Sûdî Bey'in Osmanlı Arşivi’nde yer alan sicil kaydında Hicrî ve Mâlî (Rumi) tarihler verilmektedir. Ancak aynı olay için verilen Hicrî ve Mâlî tarihlerin Türk Tarih Kurumu Tarih Çevirme Kılavuzu'nda verilen Milâdî karşılıkları birbiri ile uyuşmamaktadır. Örneğin Süleyman Sûdî Bey'in Bayezit Bidayet Mahkemesi'nde kâtip olarak ișe başlama tarihi olarak verilen 15 Şaban 1297'nin Miladî karşıllığı 23 Temmuz 1880 iken aynı olay için verilen Mâlî 9 Temmuz 1296 ise 21 Temmuz 1280 tarihine karşllı gelmektedir. Bkz: http://www.ttk.gov.tr/genel/tarih-cevirme-kilavuzu/(Erişim Tarihi: 4.12.2019). Hicrî tarihlerin tespitinde Hilâlin görülmesi esas alındığı ve bu konuda da farklılıklar yaşanabileceği dikkate alınarak bu makalede Mâlî (Rûmî) tarihlerin Milâdî karşılıkları tercih edilecektir.

${ }^{2}$ Türk Parlamento Tarihi isimli eserde Süleyman Sûdî Bey'in bu tayini ile ilgili olarak "Tokat Bidayet Mahkemesi Birinci Kâtipliğine tayin edildiği" kaydedilmekte ise de bu bilgi gerçeği yansitmamakta olup "Tutak" kelimesinin "Tokat" şeklinde yanlış okunmasından kaynaklanmaktadır. Bkz: Türk Parlamento Tarihi Milli Mücadele ve TBMM I. Dönem 1919-1923, c. III, (Yay.Haz: Fahri Coker ve Türk Parlamento Tarihi Hazırlama Grubu), TBMM Yay., Ankara, 1995, s. 159.

3 BOA.DH.SAIDd. Kutu: 174, G:281-282; http://tbmm.chp.org.tr/milletvekiliDetay.aspx?ID=5667 (Erişim Tarihi: 09.12.2019); https://www.tbmm.gov.tr/eyayin/GAZETELER/WEB/MAZBATALAR /TBMM/d02/HT_47_1_2.pdf (Erișim Tarihi: 9.12.2019). Süleyman Sûdî Bey'in II. TBMM'ne mebus seçildiğinde kendi imzasıyla Meclise verdiği 25 Eylül 1923 tarihli kısa Tercüme-i Hâl Kâğıdında "(12)99 senesinde Adliyeye muvazzafen intisab ve (1)320 senesi nihayetine kadar bilâ-fâsıla mahkeme başkitâbetlerinde istihdam" olunduğu kaydedilmektedir. Ancak bu bilgiler Osmanlı Arşivindeki Sicill-i Ahval kayıtları ile uyuşmamaktadır. Dört
} 
18 Mart 1909 tarihinde Meclise katılan Süleyman Sûdî Bey, Meclis-i Mebusan'in ikinci yasama döneminde de aynı görevini sürdürdü. 23 Temmuz 1912 tarihinde Meclis-i Mebusan'ın feshi ile bu görevi sona eren Süleyman Sûdî Bey memleketine geri dönmüştür. Süleyman Sûdî Bey'in bu dönemdeki (1912-1919) faaliyetleri hakkında bilgiye ulaşılamamıştır. Milli Mücadeleye katılan Süleyman Sûdî Bey, I. TBMM için yapılan seçimlerde Bayezit Mebusu seçilmiş ve 15 Mayıs 1920'de Meclis'e katılmıştır. Mecliste İçişleri ve Dilekçe Komisyonları ile Memurin Muhakematı Tetkik Kurulu'nda görev yapan Süleyman Sûdî Bey; Doğu illeri ve işgalden kurtarılan bölgeler göçmenleri için kurulan komisyonda da üye olarak bulunmuştur. $\mathrm{Bu}$ dönemde 1'i gizli celse olmak üzere 12 konuşma yapan Süleyman Sûdî Bey 4 soru önergesi ve 3 kanun teklifi vermiştir. II. TBMM'nde de Bayezit Mebusu olarak görevine devam eden Süleyman Sûdî Bey 7 Ocak 1928 tarihinde Bayezit'te vefat etmiştir. Evli ve üç çocuk babası olan Süleyman Sûdî Bey'in ailesi (ACARBAY) soyadını almıştır'.

Süleyman Sûdî Bey’in eşi Lütfiye Acarbay'a 15 Aralık 1948 tarih ve 5269 sayıl1 "Sivas Kongresince Seçilen Temsil Heyeti Üyeleriyle Türkiye Büyük Millet Meclisinin Birinci Döneminde Bulunan Üyelere Vatanî Hizmet Tertibinden Aylık Bağlanması Hakkında Kanun" ve bu kanunun 4. Maddesini değiştiren 24 Temmuz 1951 tarih ve 5814 sayılı kanun kapsamında 175 lira aylık bağlanmıştır (Resmi Gazete, Sayı: 20 Aralık 1948: 1; Resmi Gazete, 24 Temmuz 1951: 1; Resmi Gazete, 1 Mart 1968: 178).

\section{Süleyman Sûdî Bey'in Mebus Seçilmesi}

II. Meşrutiyetin İlanı'ndan sonra toplanacak olan Meclis-i Mebusan için ülke çapında seçimler yapılmıştır. Bu çerçevede Bayezit Sancağı'nda yapılan seçimlerde; Süleyman Sûdî Bey 14 oy, Karakilise Bidayet Mahkemesi Başkâtibi Şamil Efendi 9 oy ve Meclis-i İdare Başkâtibi Abdülkerim Efendi de 9 oy* almıştır. Heyet-i Teftişiye ve Liva İdare Meclisi; Süleyman Sûdî Bey'in Eleşkird Bidayet Mahkemesi Başkâtipliği sırasında hakkındaki şikayetler ve kanuna aykırı hareketlerinden dolayı azledilerek yargılanmış olması ve bu konudaki evrakın 28 Temmuz 1908 (15 Temmuz 1324) tarihinde Vilayet İstinaf Müdde-i Umûmîliğine gönderilmiş olması, ayrıca geçmişteki suihali nedeniyle mazbata verilmemesine karar vermiştir. Eşit oy alan iki adaydan Şamil Efendi'nin de suihali nedeniyle hakkındaki şikayet ve davalar bulunduğu için Meclis-i İdare-i Livâ Başkâtibi Abdülkerim Efendi'nin seçimi kazandığına dair mazbata hazırlanmıştır (Meclis-i Mebusan Zabit Ceridesi**, Devre: 1, İçtima Senesi: 1, İn'ikâd: 6, c. 1, s. 71). Abdülkerim Efendi'nin, seçim hakkında kararı veren Liva İdare Meclisi Başkâtibi olması, dikkati çeken bir husustur.

Meclis-i Mebusan'ın mebus mazbatalarını inceleyen Dördüncü Encümeni'nce incelenmiş ve Bayezit Livası İdare Meclisi'nin kararı doğrultusunda "işbu intihap aleyhine bir taraftan bir şikâyet de vuku bulmamış olduğundan" ifadesiyle Abdülkerim Efendi'nin mazbatasının onaylanmak üzere Genel Kurula sevkine karar verilmiştir. (Encümen Mazbatasında "şikayet olmadığı" belirtilmiş olsa da Süleyman Sûdî Bey'in Meclis-i Mebusan'a bir şikayetinin olduğu, Meclis-i Mebusan'ın 31 Aralık 1908 tarihli toplantısındaki kayıtlardan anlaşılmaktadır). Bu Encümen mazbatası Meclis-i Mebusan'ın 28 Aralık 1908 (15 Kanunuevvel 1324) tarihinde yapılan toplantısında görüşülmüştür. Encümen adına Yanya Mebusu Müfit Bey mazbata hakkında bilgi verirken Kanun-1 Esasi'nin 68. maddesinde sayılan sebeplerden "sui ahval ile müştehir olan: kötü halleriyle tanınanlar mebus olamazlar" (Düstûr, 1299; 12-13) hükmünden

satırlık özet bir belge olan Tercüme-i hâl kâğıdında, ay-gün verilmediği gibi senenin de Hicrî mi? yoksa Rûmî mi olduğu da belirtilmemiştir. Bundan dolayı Süleyman Sûdî Bey'in hayatı kısmını yazarken daha ayrıntılı olan Sicill-i Ahvâl kaydı esas alınmışıır.

4 Türk Parlamento Tarihi Milli Mücadele ve TBMM I. Dönem 1919-1923, c. III, s. 159-160; https://www.tbmm.gov.tr/eyayin/GAZETELER/WEB/MAZBATALAR/TBMM/d02/HT_47_1_2.pdf (Erişim Tarihi: 9.12.2019); http://tbmm.chp.org.tr/milletvekiliDetay.aspx?ID=5667 (Erişim Tarihi: 09.12.2019)

* O dönemde seçimler iki dereceli yapılmakta, oy verme yeterliliğine sahip erkekler "müntehib-i evvel: birinci seçmen" olarak "müntehib-i sânîleri: ikinci seçmenleri" seçmekte, bu ikinci seçmenler de mebusları seçmekteydi. Burada geçen 14 veya 9 rakamları ikinci seçmenleri ifade etmektedir.

** Meclis-i Mebusan Zabıt Ceridesi isimli eser bundan sonra "MM.ZC." şeklinde kısaltılarak verilecektir. 
dolayı Encümenin bu karara vardığını söylemiștir. Bunun üzerine mebuslardan (zabıt ceridesinde de ismi tespit edilemeyen) birisi; kimin mebus olacağına ikinci seçmenlerin oylarıyla karar verileceğini, Heyet-i Teftişiye'nin kaza yetkisi (yargı yetkisi) bulunmadığı için mebus seçilme yeterliliğine karar veremeyeceğini, çok oy alanların adaylı̆̆ reddedilirse yeniden seçim yapılması gerektiğini savunmuştur. Dolayısıyla da bu mazbatanın onaylanamayacağı, diğer adayların evrakının Meclisçe incelenmesi gerektiğini vurgulamıştır. Bu görüşü destekleyen Kozmidi Efendi (İstanbul), Kanun-1 Esasî'ye göre seçilen mebusun mebusluğunun geçerli olup olamayacağına Meclis-i Mebusan'ın karar verebileceğini, dolayısıyla da çok oy alarak seçilen mebusa mazbata verilmesi ve evrakının Meclis'te incelenmesi gerektiğini iddia etmiştir. Yine ismi tespit edilemeyen bir mebus da; Heyet-i Teftişiye'nin görevinin seçimlere nezaret etmek olduğunu, bu olayda olduğu gibi takdir yetkisinin bulunmadığını söylemiştir. Ankara Mebusu Talât Bey de; en fazla oyu alan kişinin mebus seçilmiş kabul edilmesi, eğer seçilme yeterliliğine sahip olmadığ anlaşılırsa önceki seçimin iptale edilerek yeniden seçim yapılması gerektiğini ifade etmiştir. Yapılan oylamada oy çokluğu ile Süleyman Sûdî Bey'e mazbata verilerek Meclis'e gönderilmesi kabul edilmiştir (15 Kanunuevvel 1324/28 Aralık 1908). (MM.ZC., Devre: 1, İçtima Senesi: 1, İn'ikâd: 6, c. 1, s. 71-72).

Bu karara rağmen konu Meclis-i Mebusan'ın 31 Aralık 1908 (18 Kanunuevvel 1324) tarihli toplantısında Bayezit Mebusluğuna dair mazbatayla ilgili tartışmalar devam etmiştir. Oturumu yöneten Meclis Reisi Ahmet Rıza Bey, konuyu özetledikten sonra Süleyman Sûdî Bey'in şikayetine karşılık olarak; ya şikayetin reddi, veyahut mazbatasının gönderilmesi şeklinde cevap verilmesi gerektiğini söylemiştir. Bunun üzerine söz alan Gümülcineli İsmail Hakkı Bey; Meclisin daha önce bu konuyla ilgili karar vermiş olduğunu belirterek, konu üzerinde tekrar tartışma açılmasının doğru olmadığını, Süleyman Sûdî Bey'e mazbatanın verilmesi ve bu mazbatanın da Mecliste incelenerek sonuçlandırılmasının gerektiğini savunmuştur. Mazbataları inceleyen Encümen Üyesi Müfit Bey ise; Süleyman Sûdî Bey'in mazbatayı alıp İstanbul'a gelmesi halinde, eğer mazbatası reddedilirse tekrar geri gitmek durumunda kalacağını, buna gerek kalmaması için Süleyman Sûdî Bey'in mazbatasıyla ilgili kendisi gelmeden karar verilmesini önermiştir. Ancak Gümülcineli İsmail Hakkı Bey, mebusun mazbatasını alıp Meclise gelmesi ve yapılacak incelemeden sonra karar verilmesinde 1srar etmiştir. Kozmidi Efendi de bu görüşü desteklemiştir. Dersim Mebusu Lütfi Fikri Bey ise; biri Heyet-i Teftişiyenin diğeri kanunun mebusu olarak iki mebusun bulunduğunu, konunun çözümü için Heyet-i Teftişiyenin verdiği mazbata ve mebusluğu reddedilen adaylarla ilgili bütün evrakın mahallinden istenilmesi için Hükümete yazı yazılmasını teklif etmiştir. Bu teklif diğer mebuslarca da kabul edilmiştir (18 Kanunuevvel 1324/31 Aralık 1908) (MM.ZC., Devre: 1, İçtima Senesi: 1, İn'ikâd: 8, c. 1, s. $103-$ 104).

Süleyman Sûdî Bey'in şikayeti üzerine Meclis-i Mebusan'da alınan bu karar üzerine, Mazbatalarla ilgili olarak zaten Meclis-i Mebusan'ca inceleme yapılacağından en fazla oyu alan Süleyman Sûdî Bey'e mazbatanın verilmesi gerektiğine dair Meclis-i Mebusan Riyaseti'nden Sadaret'e tezkere yazılmıştır (27 Kanunuevvel 1324/ 9 Ocak 1909). Sadaret'ten de aynı tarihte Dahiliye Nezareti'ne gönderilen yazıda; Meclis-i Mebusan'ın kararı doğrultusunda Süleyman Sûdî Bey'e mazbatanın verilmesi için mahalline tebligat yapılması istenilmiştir (BOA. BEO., D: 3468, G: 260061, V: 1).

Dahiliye Nezareti'nin tebliği gereğince Bayezit Mebusluğu için Süleyman Sûdî Bey adına mazbata düzenlenerek kendisine verilmiştir (16 Mart 1909). Süleyman Sûdî Bey'in mebus seçildiğine dair mazbatası ve diğer evrak Birinci Şube Tetkik-i Mazâbıt-1 İntihabiye Encümeni'nce incelenmiştir. Bayezit'ten gönderilen evrak içerisinde Süleyman Sûdî Bey'in aleyhinde "mütegallibeden ve sû-i şöhret (zorba ve kötü şöhretli)" yanında, lehinde ifadelerin de yer alması ve suçlamaların delillere dayanmaması nedeniyle Encümen, Süleyman Sûdî Bey'in mebus mazbatasının onaylanmasına karar vermiş ve bu kararını Meclise sunmuştur (28 Şubat 1324/13 Mart 1909). Bu Encümen kararı Meclis-i Mebusan'ın 15 Mart 1909 (2 Mart 1325) tarihli Genel Kurul toplantısında okunmuştur. Konuyla ilgili olarak sadece Halep Mebusu Nâfi Paşa söz 
almış ve şüphelerle kimsenin medeni haklarından yoksun bırakılamayacağını ifade etmiştir. Yapılan oylamada Süleyman Sûdî Bey'in mazbatası tasdik edilmiştir. Süleyman Sûdî Bey, 18 Mart 1909 tarihinde Meclis-i Mebusan'a katılmıştır (MM.ZC., Devre: 1, İçtima Senesi: 1, İn'ikâd: 41, c. 2, s. 294-295; Güneş vd., 1998:159).

\section{Süleyman Sûdî Bey’in Meclis-i Mebusan'daki Faaliyetleri}

Süleyman Sûdî Bey'in Meclis-i Mebusan'daki ilk yasama faaliyeti İran ve Rusya sınırındaki askerlerin donanımları ve ihtiyaçlarının karşılanmasıyla ilgili takrir vermesidir. Süleyman Sûdî Bey'in Rusya ve İran sınırlarındaki Dördüncü Orduya mensup askerlerin donanımları hakkındaki 12 Mart 1325 (25 Mart 1909) tarihli takriri (önerge) Meclis-i Mebusan'ın 12 Haziran 1909 tarihinde yapılan toplantısında Meclis Genel Kuruluna okunmuştur. Bu takrirde; vatanın korunması için çeşitli zorluklara göğüs geren kahraman askerlere vaktiyle şilte, yağmurluk, elbise, çamaşır ve çizme verilemediği, bu sebeple Rus askerleriyle kıyaslandığında donanımlarının yetersiz olduğu ve ikamet ettikleri yerlerin sağlık koşullarının uygun olmadığı belirtildikten sonra bu durumun vatan savunması için tehlikelere yol açacağı vurgulanmıştır. Bu olumsuzlukların giderilmesi için 1-2 kilometre aralıklarla gözetleme kuleleri inşa edilmesi, tayin denilen askerlerin günlük yiyecek ve içeceklerinin birkaç asker gönderilerek saatlerce uzaklıkta bulunan dağıtım yerlerinde dağıtılması yerine görevi başında verilmesi, her birlikte yeterli miktarda nakliye hayvanı bulundurulması ve böylece sinırlarda görev yapan askerlerin ihtiyaçlarının karşılanması talep edilmektedir. Bu takrir yapılan oylamada Harbiye Encümenine havale olunmuştur (MM.ZC., Devre: 1, İçtima Senesi: 1, İn'ikâd: 91, c. 4, s. 329-330).

31 Mart İsyanı'nın çıkması üzerine oluşturulan Hareket Ordusu, İstanbul'a gelmiş ve isyanı bastırmıştır. İsyanın bastırılması aşamasında III. Ordu ve Hareket Ordusu Kumandanı Mahmut Şevket Paşa tarafından 12 Nisan 1325 (25 Nisan 1909) tarihinde İstanbul ve çevresinde İdare-i Örfiye: Sıkıyönetim ilan edilmiş ve bu karar Meclis'e bildirilmiştir. İdare-i Örfiye ilanına dair karar Meclis-i Mebusan ve Meclis-i Ayan'ın birlikte toplanmasıyla oluşan Meclis-i Umumi'nin aynı tarihli toplantısında görüşülmüştür. Bu idare-i örfiyenin süresi Mecliste uzun uzadıya tartışılmış ve çok sayıda takrir (önerge) verilmiştir. Bu takrirlerden birisi de Süleyman Sûdî Bey'e aittir. Süleyman Sûdî Bey takririnde; "müddet tayin ve tahdidi icap etmeyip Hareket Ordusu Kumandanlı̆̆ının talebi üzerine memleketin iade-i asayişine değin muvakkaten idare-i örfiyenin tasdiki"ni teklif etmiştir. Diğer takrirler reddedilirken Süleyman Sûdî Bey'in takriri 107 oyla kabul edilmiş ve ülkede asayiş sağlanıncaya kadar geçici olmak kaydıyla idare-i örfiye ilanı kararı Meclis-i Umumi tarafından tasdik edilmiştir (12 Nisan 1325/25 Nisan 1909). (Meclis-i Umumi Zabıt Cerideleri, Devre: 1, İçtima Senesi: 1, İn'ikâd: 3, c. 1, s. 32).

Süleyman Sûdî Bey'in Süvari Alaylarında (Hamidiye Alayları) bazı rütbedeki subayların fazla olduğuna dair takririnin özeti Meclis-i Mebusan'ın 17 Mayıs 1909 (4 Mayıs 1325) tarihli toplantısında okunmuş ise de bu konuların Harbiye Nezareti'nin görev alanına girdiği gerekçesiyle yapılan oylamada takrir Mecliste görüşülmeye değer bulunmamıştır (MM.ZC., Devre: 1, İçtima Senesi: 1, İn'ikâd: 73, c. 3, s. 489).

İzinli olarak memleketlerine giden, ancak geri dönmeyen/süre ihlâlinde bulunan mebuslar hakkında bir karar alınmasına yönelik olarak Süleyman Sûdî Bey ve üç mebus tarafından Meclisi Mebusan'a sunulan takrir(önerge) Meclisin 17 Ağustos 1909 tarihli toplantısında okunmuştur. Takrirde; mazeretlerine binaen izin alan mebusların Meclisten izin süresini uzatmak için Meclise başvurmalarının Meclisin çalışmalarını aksattığı belirtilerek bu konuda bir karar alınması talep edilmektedir. İzmir Mebusu Seyyid Bey'in bu maddelerde geçen tabirin tefsirine ihtiyaç bulunması nedeniyle Kanun-1 Esasî'nin tefsiri/yorumlanması yetkisinin Ayan Meclisi'nde olmasından dolayı bu takririn oraya gönderilmesi teklifi kabul edilmiştir (MM.ZC., Devre: 1, İçtima Senesi: 1, İn'ikâd: 136, c. 6, s. 504-505).

Süleyman Sûdî Bey'in Meclis-i Mebusan'daki bir diğer yasama faaliyeti 15 Ocak 1910 (2 Kanunusani 1325) tarihinde Meclise sunduğu "1293 muharebesinin tevlit ettiği gaileden bilistifade Rusya tarafından Iran'a verilen Bayezit Sancă̆ına bă̆lı Kazlıgöl mevkii ile Tombat 
ve Yarımkaya karyelerinin hududu Osmanîye iadesi hususunun temini babında Iran Hükümeti ile temasa geçilmesine dair takriri" olmuştur. Süleyman Sûdî Bey bu takririnde; Bayezit Sancağı'nın İran sınırında bulunan ve genişliği yüz (100) kilometre kareyi bulan Kazlıgöl mevkii ile Tombat ve Yarımkaya köylerinin Osmanlı Devleti'ne ait olduğu resmi kayıtlarda yer almakta olduğu, bu durumu yöre halkının bildiği ve yapılan yazışmalarda da yer aldığı halde Rusya'nın Doksanüç Harbi (1877-1878 Osmanl1-Rus Savaşı) sırasındaki kargaşa ortamından da yararlanarak bu toprakları İran'a verdiğini anlatmıştır. Halka karşı baskı uygulayan Maku ve Avaclık Hanlarının ellerine geçmiş olan bu toprakların geri alınması için yerel yetkililerin devam ede gelen başvurularına rağmen Bab-1 Âlî (Osmanlı Hükümeti) tarafından ciddi bir karar alınmamasının vatanseverleri üzmekte olduğunu ifade eden Süleyman Sûdî Bey, nice şehitlerin kanı pahasına alınan toprakların menfaatlerinden başka bir şey düşünmeyen eski yönetimin tembellik ve vurdumduymazlıklarına kurban edilmekte olduğunu belirtmiştir. Kazlıgöl denilen bölgede İran yönetiminin dokuz-on adet köy kurduğunu ve buralara birtakım eşkıyayı iskân ettiğini, gerek buralarda ve gerekse Tombat ve Yarımkaya köylerinin sınırlarının kesin olarak belirlenmemiş olması dolayısıyla birçok karışıklığın yaşandığını belirten Süleyman Sûdî Bey; yetkililerin ihmal ve kayıtsızlıkları nedeniyle Milletin haklarının pâyimâl edildiğini ve Maku Hanı'nın yaz aylarında bölgeye sevk ettiği aşiretler ve eşkıyaların sınırda karışıklıklara, çatışmalara ve çekişmelere neden olduğunu ifade etmiştir. İran Devleti ve Erzurum Vilayeti ile gerekli yazışmaların yapılarak sınırın tespiti ve İran'a geçmiş olan arazinin geri alınmasını isteyen Süleyman Sûdî Bey; sınırda yaşanan olayların önüne geçilebilmesi için gerekli tedbirlerin (gözetleme kuleleri yapılması, asker bulundurulması vs.) alınmasının gerekliliğini savunmuş ve önergesinin Mecliste okunması ve ilgili makamlara iletilmesini talep etmiştir. Önergenin okunmasından sonra söz alan bazı mebuslar; (Üsküp Mebusu Sait Efendi, Erzurum Mebusu Ohannes Varteks Efendi, Denizli Mebusu Gani Bey, Kengırı (Çankırı) Mebusu Mehmet Tevfik Efendi) konuyla ilgili görüşlerini ifade etmişlerdir. Mebusların meşruti yönetimde hangi konularda, hangi gerekçe ile takrir verecekleri konusundaki acemiliklerine vurgu yapan Dersim Mebusu Lütfi Fikri Bey; bu takririn bir soru önergesi mi? Veya kanun teklifi mi olduğunun belli olmadığını belirttikten sonra bu tür durumlarda mebusların önce Hükümet yetkililerine konuyu iletmeleri, eğer dikkate alınmaz ise soru önergesi şeklinde Meclisin gündemine taşımaları gerektiğini savunmuştur. Bunun üzerine söz alan Süleyman Sûdî Bey; aynı konuda daha önce verdiği takririn dikkate alınmaması nedeniyle üçüncü kez takrir hazırladığını ve Meclis Genel Kurulundan önce firka ve şubelerde okunduğunu belirtmiştir. Yapılan tartışmaların sonucunda takririn(önergenin) Mecliste görüşmeye değer olup olmadığı oylanmış ve kabul edilmiş ve daha sonra da takririn Sadarete havalesi kararlaştırılmıştır (MM.ZC., Devre: 1, İçtima Senesi: 2, İn'ikâd: 25, c. 1, s. 530-532).

Süleyman Sûdî Bey'in Meclis gündemine taşıdığı bir diğer konu "Trabzon-Erzurum demiryolunun bir an evvel yapılması" ile ilgilidir. Süleyman Sûdî Bey'in öncülügünde 71 mebus tarafından da imzalanarak Meclis Başkanlığına takdim edilen 5 Kanunusani 1325 (18 Ocak 1910) tarihli takrir Meclis-i Mebusan'ın 7 Şubat 1910 tarihinde yapılan toplantısında görüşülmüştür. Daha önce Trabzon ve Samsun Vilayetleri İdare Meclislerince iki liman üzerinden taşınan ticari mallarına oktruva resmi (şehirlere dışarıdan getirilen mallardan alınan giriş vergisi) konulması ve bu vergiler karşlık gösterilerek Samsun-Sivas ve Trabzon-Erzurum demiryolu hatlarının inşa edilmesinin gündeme geldiği belirtilen takrirde Trabzon-Erzurum hattının yapımının gerekçeleri şu şekilde belirtilmiştir: Trabzon limanının Karadeniz kıyısındaki en önemli limanlardan olması, Anadolu'nun önemli bir kesimi (Erzurum, Bitlis, Van, Diyarbakır ve Mamüratülaziz vilayetleri) ile Osmanlı Dördüncü Ordusu ve İran'ın dünyaya açılan tek kapısı olması, bu bölgedeki posta ve ticari nakliyenin yegâne güzergâhı olması. Ulaşımın yeterli olmamasının bölge şehirleri için ekonomik kayba sebep olduğu savunulan takrirde; her açıdan önemli faydalar sağlayacak olan Trabzon-Erzurum Demiryolu hattının bir an evvel inşasının gerekliliği vurgulanmıştır. Takririn Genel Kurulda okunmasından sonra Artas Yorgaki Efendi (Selânik), Mebusu İsmail Paşa (Tokat) ve İsmail Mahir Efendi (Kastamonu) konu ile ilgili görüşlerini açıklamışlardır. Takrir üzerinde söz alan diğer mebusların demiryolu hattının yapımının gerekliliği ve askeri-siyasi-ekonomik 
açıdan faydalarına dair konuşmalarında tartışmanın odak noktasını, yapılacak demiryolu hattının Trabzon limanına mı, yoksa Samsun limanına mı bağlanması gerektiği konusu oluşturmuştur. Yapılan tartışmalardan sonra acele olarak yapılmak üzere takririn Nafıa Nezaretine gönderilmesi kabul edilmiştir (MM.ZC., Devre: 1, İçtima Senesi: 2, İn'ikâd: 37, c. 2, s. 190-193).

Süleyman Sûdî Bey'in de içinde bulunduğu bir grup mebus tarafindan verilen ve Meclisi Mebusan'ın 14 Ağustos 1909 tarihinde yapılan toplantısında görüşülen takrirde; bazı suçluların affına dair İrade-i Seniyye'de geçen "Kürdistan” tabirinin şümulüne hangi vilayetlerin dâhil bulunduğu huşunda karar alınması istenilmekteydi. Takrir okunduktan sonra yapılan tartışmalardan sonra, metinde geçen bu tabirin yorumunun Hükümete bırakılması ve takririn Adliye Nezareti'ne gönderilmesi kabul edilmiştir (MM.ZC., Devre: 1, İçtima Senesi: 1, İn'ikâd: 133 , c. 6, s. 396-398).

Süleyman Sûdî Bey 25 Teşrinisani 1327 tarihli istizah takririnde (soru önergesi) Erzurum-Bayezit karayolunun bitirilmemesinin sebepleri hakkında açıklama talep etmiştir. Meclis-i Mebusan'ın 11 Aralık 1911 tarihli toplantısında okunan takrirde; ekonomik kalkınma, doğal kaynaklardan yararlanma, ticaretin gelişmesi vesair açıdan yolların önemi vurgulayan Süleyman Sûdî Bey, Trabzon-Erzurum-Bayezit yolunun* tamir edilememesinden dolayı İran ticaretinin Rusya üzerinden yapılması nedeniyle ülkenin gelir kaybı yaşandığını, ayrıca ordunun sevkiyatı için de önemli bir güzergâh olan Erzurum-Bayezit yolunun bir an önce tamamlanması için defalarca başvuruda bulunduğunu anlatmıştır. Son başvurusu olan 2 Mayıs 1327 (15 Mayıs 1911) tarihli başvuruya bahsi geçen yolun gelecekte inşa edilmesi planlanan tâlî (ikinci derecede) yollar listesinde olduğu cevabının verildiğini belirten Süleyman Sûdî Bey, Erzurum-Bayezit yolunun bir an önce inşası için Hariciye Nezareti'nin bir tezkeresinin de bulunduğu ifade etmiştir. $\mathrm{Bu}$ yolun önemi Hariciye ve Nafia Nezaretleri ile Sadaret tarafından da tasdik edilmesine rağmen bu yolun inşasının ertelenmesi ve halktan alınan tarîk bedel-i nakdîsinin (yol mükellefiyeti vergisi) başka yerlere harcanmasının doğru olmadığını savunan Süleyman Sûdî Bey, ekonomik ve askeri açıdan çok önemli olan Erzurum-Bayezit karayolunun yapılmamasının sebepleri hakkında Nafia Nezareti'nden açıklama talep etmiştir. Önerge kabul edilerek cevaplandırılmak üzere Nafia Nezareti'ne gönderilmiştir (MM.ZC., Devre: 1, İçtima Senesi: 4, İn'ikâd: 23, c. 2, s. 125-126).

Süleyman Sûdî Bey'in bu soru önergesini Nafia Nazırı Hulusi Bey, Meclis-i Mebusan'ın 23 Aralık 1911 tarihli toplantısında cevaplandırmıştır. Erzurum-Bayezit yolunun neden yapılmadığı sorusunu, sadece bu yol için değil, bütün ülkeyi dikkate alarak cevaplandırmak istediğini belirterek sözlerine başlayan Hulusi Bey; Meşrutiyetin ilanından sonra yolların "turuk1 umumiye: ana yollar" ve "turuk-1 vilayat: il yolları" şeklinde iki kısma ayrıldığını, ErzurumBayezit Yolu'nun il yolları/tâlî yollar grubundan bulunduğu ifade etmiştir. Vilayet yollarının o vilayete tahsis edilen tarik bedel-i nakdî (yol vergisi) miktarına göre Vilayet İdare Meclisi tarafından yapılacak yolların öncelik sırasına göre yapımının gerçekleştirilmekte olduğunu söyleyen Hulusi Bey; Erzurum Vilayeti için ayrılmış olan ödeneğin yetersizliği nedeniyle bırakın yeni yol yapmayı, var olanların tamirinin bile zor olduğunu ifade etmiştir. Hulusi Bey, ErzurumBayezit yolunun yapımı için 137.252 lira gerektiğini, bunun da yıllık yol vergisi miktarı 8 bin lira olan Erzurum Vilayeti'nin 17 yıllık tahsisatına karşılık geldiğini, Vilayet Meclisinin toplam miktarı vilayet dahilindeki bütün sancak ve kazalara ayırdığı için bu yol için ödeneğin yeterli gelmediği anlatmıştır. Hulusi Bey, Vilayet meclislerinin tahsis edilen ödeneği vilayet dahilindeki bütün yollara eşit olarak dağıtmasıyla yolların bitirilemediğini, bunun yerine yapılacak yolları öncelik sırasına koyup bütün ödeneği o sıraya göre bir güzergaha harcayarak yol yapımında ilerleme sağlanabileceğini savunmuştur. Erzurum Mebusu Ohannes Varteks Efendi'nin ErzurumBayezit yolunun Hükümetin sorumluluğundaki "umumi: ana yol” kapsamına alınmasına dair ifadesi üzerine Hulusi Bey, sual takriri metninde böyle bir istek yer almadığını ancak hangi

\footnotetext{
* Trabzon-Erzurum-Bayezit Yolu çok önemli bir ulaşım güzergâhı olup bu yolun tarihi süreci ile ilgili ayrıntılı bilgi için bakınız: Selâhattin Tozlu, Trabzon-Erzurum-Bayezit Yolu (1850-1900), Atatürk Üniversitesi Sosyal Bilimler Enstitüsü, Yayınlanmamış Doktora Tezi, Erzurum, 1997, s. 1-296.
} 
yolların ana yollar kapsamına alınıp-alınmamasıyla ilgili olarak ileride Meclise bir teklif getirileceğini söylemiştir. Bunun üzerine söz alan Süleyman Sûdî Bey; takrirde tam olarak belirtilmese de bu yolun ana yollar kapsamına alınmasının gerekli olduğunu vurgulamıştır. Süleyman Sûdî Bey, vilayet bütçesi ile tamamlanmas1 mümkün olmayan Erzurum-Bayezit Yolu'nun ana yollar kapsamında yapılmasını Meclis'ten talep etmiş ve Nafia Nazırının da yardımını istemiştir (MM.ZC., Devre: 1, İçtima Senesi: 4, İn'ikâd: 28, c. 2, s. 269-271). Süleyman Sûdî Bey Erzurum-Bayezit yolunun yapılmasıyla ilgili olarak takibini devam ettirmiş ve 1912 Y1lı Nafia Nezareti Bütçesi görüşülürken de söz alarak bu yolun bir an önce umumi yollar arasına alınmasını teklif etmiştir (MM.ZC., Devre: 2, İçtima Senesi: 1, İn'ikâd: 41, c. 2, s. 480-481; MM.ZC., Devre: 2, İçtima Senesi: 1, İn'ikâd: 42, c. 2, s. 525-526).

Süleyman Sûdî Bey, Dahiliye Nezareti'ne sunduğu 22 Mayıs 1327 (4 Haziran 1911) tarihli arzuhalde; Bayezit Sancağı'na bağlı "Karakilise" kazası bulunduğu gibi, Pasinler Kazası'na bağlı Karakilise adıyla bir nahiyenin bulunduğunu ve aynı şekilde "Kırkkilise", "Kızılkilise" isimleriyle sancak ve kazaların mevcut olduğunu belirtmiştir. İsim benzerliğinin posta haberleşmesinde ve yazışmalarda karışıklıklara neden olduğunu savunan Süleyman Sûdî Bey, bunun önüne geçmek amaciyla daha önce Anadolu Müfettiş-i Umumîsi Şükrü Paşa'nın da önerdiği gibi Bayezit'a bağlı "Karakilise" kazasının isminin "Yıldırım" veya "Muradiye" şeklinde değiştirilmesini talep etmiştir. Dahiliye Nezareti bu arzuhal üzerine Erzurum Valiliği'nden görüş sormuştur. Erzurum Valisi Mehmed Celal imzasıyla 18 Haziran 1327 (1 Temmuz 1911) tarihiyle verilen cevapta; konunun Vilayet İdare Meclisi’nde görüşüldügünü ve kaza isminin değiştirilmesine lüzum görülmediği belirtilmiştir (BOA. DH.İD. D: 97-1, G: 25, V: $1-3)$.

Dahiliye Nezareti’nin 1911 Yılı Bütçesi görüşülürken bir önerge veren Süleyman Sûdî Bey; Erzurum Vilayetine bağlı kazaların çoğunda belediye gelirlerinin yetersizliği nedeniyle Belediye Doktoru istihdam edilemediğini belirterek, Bayezit Sancağı merkez ve kazalarına Nezaret kadrosuyla birer doktor tayin edilmesini istemiştir. Yapılan oylamada önerge kabul edilmemiştir (20 Mayıs 1911) (MM.ZC., Devre: 1, İçtima Senesi: 3, İn'ikâd: 102, c. 6, s. 714).

Maarif Nezareti'nin 1911 Yılı Bütçesi Meclis-i Mebusan'da görüşülürken söz alan Süleyman Sûdî Bey; bir süre önce Erzurum halkı adına Nezarete çekilen telgraflarda Erzurum İdadi Mektebi'ne öğretmen gönderilmediği için okulda eğitim yapılamadığının belirtildiğini hatırlattıktan sonra, bizzat idadiyi ziyaret ettiğini, binanın tamir ve bakıma ihtiyacı bulunduğunu, öğretmen olmadığı için derslerin boş geçtiğini anlatmıştır. Konuşmasının devamında bir önceki Nâzır Emrullah Efendi'nin Bayezit Sancağı'nda bir idadi ve darülmuallimin açmayı vaat ettiğini belirten Süleyman Sûdî Bey, nâzır değişikliği nedeniyle bu vaadin gerçekleşemediğini, yeni nâzırdan bu okulların açılması konusunda yardım talep etmiştir (20 Mayıs 1911) (MM.ZC., Devre: 1, İçtima Senesi: 3, İn'ikâd: 102, c. 6, s. 728). 22 Mayıs 1911 tarihinde Maarif Nezareti Bütçesinin görüşmelerine devam edilmiş ve Süleyman Sûdî Bey, Emrullah Efendi tarafından vaat edilen Bayezit'te idadi mektebi açılması için bir önerge vermiş ise de kabul edilmemiş̧tir. Yapılan konuşmalardan sonra bütçe kabul edilmiştir, ancak Süleyman Sûdî Bey'in bahsettiği hususlarda Nâzır herhangi bir açıklama yapmamıştır. Arnavutluk, Arabistan ve Kürdistan bölgelerinde 9 adet yatılı rüştiye açılmasıyla ilgili madde görüşülürken bir önerge veren Süleyman Sûdî Bey, bu rüştiyelerden birisinin Bayezit'te açılmasını istemişse de bu öneri de kabul görmemiştir (MM.ZC., Devre: 1, İçtima Senesi: 3, İn'ikâd: 104, c. 7, s. 47, 69).

Adliye Nezareti Bütçesi üzerinde söz alan Süleyman Sûdî Bey; Bayezit Sancağı'nda mahkeme üyeleri ve kâtiplerin sayısını yetersizliği nedeniyle yargılamaların geciktiğini ve bundan dolayı halkın mağduriyetler yaşadığını belirterek personel eksikliğinin giderilmesini talep etmiştir. Ancak bütçeye bu konuda ödenek eklenmemekle birlikte Nezâret yetkilileri tarafindan; bütçe kabul edildikten sonra kâtip fazlalığı olan yerlerden personel nakli yapılacağına dair bir açıklama yapılmıştır (27 Temmuz 1912). (MM.ZC., Devre: 2, İçtima Senesi: 1, İn'ikâd: 41, c. 2 , s. $464-465,468)$. 
Meclis-i Mebusan'da Düyûn-1 Umumiye Bütçesi görüşülürken söz alan Mehmet Tevfik Efendi, I. Dönem mebuslarından Hoca Şevket Efendi'nin istibdat döneminde meşrutiyet taraftarı olduğu için işkencelere maruz kaldığı için sağlığının bozulduğunu belirterek hidemât-1 vataniye tertibinden maaş bağlanmasını teklif etmiştir. Bunun üzerine söz alan Süleyman Sûdî Bey, Şevket Efendi'nin işkenceler dolayısıyla gözlerinin de görmediğini herhangi gelir getirecek bir işte çalışamayacak kadar malul bulunduğunu anlatarak Tevfik Efendi'nin teklifini desteklemiştir. Teklifleri cevaplandıran Maliye Nâzırı Cavit Bey, hidemât-1 vataniye tertibinde ödeneğin az olması nedeniyle Hoca Şevket Efendi'ye ve ailesine mağdurin-i siyasiye tertibinden 500 kuruş maaş tahsisini teklif etmiş ve Meclis tarafindan kabul edilmiştir (4 Temmuz 1912). (MM.ZC., Devre: 2, İçtima Senesi: 1, İn'ikâd: 26, c. 2, s. 58-59). Meclis görüşmelerinde açikça belirtilmemekle birlikte maaş bağlanan kişinin II. Meşrutiyet'in birinci döneminde Erzurum Mebusluğu yapan ve Süleyman Sûdî Bey gibi Ahali Fırkası'nın kurucuları arasında yer alan medrese mezunu Hacı Şevket Efendi olması muhtemeldir (Güneş vd, 1998: 360).

\section{Süleyman Sûdî Bey’in Mektuplarının Erzurum Valisi Celal Bey Tarafindan Açılması Meselesi}

Mektupların açılması meselesi, Erzurum Valisi Celal Bey'in Dahiliye Nezareti'ne gönderdiği bir telgrafla başlamaktadır. Bu telgrafta; "Erzurum ve çevre vilayetlerde asayişin bozulduğu, bunun halkta korku ve heyecana neden olduğu ve bundan dolayı bazı Kürt aşiret reislerinin Rusya ve İran'a topluca göç etmek için hazırlık yaptıklarına" dair yayılan söylentinin ve yalan haberlerin Bayezit Mebusu Süleyman Sûdî Bey'den kaynaklandığının kesin olarak anlaşıldığını iddia etmiştir. Süleyman Sûdî Bey'in aşiret reislerine yazdığı mektuplardan ikisinin "sevk-i tesadüfle" elde edildiğini belirten Vali Celal Bey; el yazısı olan mektupların asıllarının her ihtimale karşı Erzurum Valiliği'nde saklanacağını, fotoğraflarının posta ile İstanbul'a gönderileceğini ifade etmiştir. Milletin haklarını savunmak üzere seçilmiş olan bir mebusun, memlekette heyecan ve Meşrutiyet Hükümetine karşı muhalefet etmeye, ayaklanmaya ve bir kısmını yurtdışına göç etmeye teşvik etmesini esef edilecek bir durum olarak niteleyen Vali Celal Bey; Kabineyi "idare-i maslahat Hükümeti" olarak eleştiren Süleyman Sûdî Bey'in mektuplarının gazetelerde neşredilmesi için Nezaretten izin istemiştir (23 Şubat 1325/8 Mart 1910). Dahiliye Nezareti'nden bir gün sonra verilen cevapta; mektupların gazete ile neşrinin münasip olmadığ 1 belirtilmekte ve mektupların fotoğraflarının hemen Nezarete gönderilmesi istenilmekteydi (BOA. DH. MUİ. D: 72, G: 79, V: 1-2).

Bunun üzerine Erzurum Valisi Celal Bey, Süleyman Sûdî Bey'in kendi el yazısıyla yazdığı, asayişsizlik nedeniyle galeyan içindeki halkın Rusya ve İran'a göç etmek için gizli hazırlık yaptıklarına dair ifadelerin yer aldığı mektuplardan birisinin fotoğrafını ve birisinin de kopyasını Nezarete göndermiştir. Vali Celal Bey yazısında, bu söylentilerin Süleyman Sûdî Bey'in uydurmaları olduğunu da belirtmektedir. Dahiliye Nazırı da bu evrakı Sadarete takdim etmiş ve Süleyman Sûdî Bey'in Meclis Başkanlığı tarafından uyarılması konusunu Sadrazamın takdirine bırakmıştır (22 Mart 1910). (BOA. DH. MUİ. D: 78, G: 66, V: 1).

Süleyman Sûdî Bey'in mektuplarının açılması konusu Meclis-i Mebusan gündemine getirilince, Dahiliye Nezareti'nden Erzurum Valiliği'ne gönderilen telgrafta; mektupların alıcısına ulaştıktan sonra elde edildiğine dair alıcıdan imzalı bir yazı alınarak Nezarete gönderilmesi istenilmiştir (8 Mayıs 1326/21 Mayıs 1910) (BOA. DH. MUİ. D: 78, G: 66, V: 6). Mektubun alıcısından bu şekilde imzalı bir belge alınıp alınmadığı arşiv belgelerinden anlaşılamamıştır.

Bir taraftan Meclis-i Mebusan'da mektupların açılmasıyla ilgili istizah (gensoru) görüşmeleri devam ederken bir taraftan da olayın yerel yankıları ve Süleyman Sûdî Bey'e karş1 tepkiler de devam etmiştir. Hatta Meclis-i Mebusan'da gensoru önergesiyle ilgili görüşmeler ve tartışmalar aşağıda ayrıntılı bir şekilde izah edileceği üzere 26 Mayıs 1910 (13 Mayıs 1326) tarihinde Dahiliye Nazırı Mehmet Talât Bey'e güvenoyu verilmesiyle sonuçlandıktan sonra bile yerel yankıları devam etmiştir. Dahiliye Nezareti'ne ve Divan-1 Harb-i Örfî Riyaseti'ne çekilen telgraflarda; Süleyman Sûdî Bey'in halkı galeyana getirmek, yönetime karşı kışkırtmak vs. 
suçlardan dolayı yargılanması ve memlekete gelmesinin engellenmesi istenilmiştir. Telgraflar her iki makama da aynı kişiler (Erzurum Müftüsü Hamid, Ermeni Murahhasası Sempad, Meclis-i İdare Azası Tevfik, Riza, Onnik ve Parsih(?) tarafindan 13 Haziran 1910 (31 Mayıs 1326) tarihinde çekilmiştir. Telgraflardaki şu ifadeler dikkat çekicidir (BOA. DH. MUİ. D: 78, G: 66, V: 11, 12): "Bayezit Mebusu Süleyman Sûdî Efendi'nin harekât ve teşebbüsât-ı vâkı'ası Kanun-ı Ceza'nın 56. maddesine tevâfuk eylediği evrâk-ı havâdisle neşredilen mektupların münderecâtıyla sâbit olduğundan memleketimizi bir ihtilâl-i azîmden kurtaran Vâlimiz Celâl Beyefendi'ye borçlu olduğumuz teşekkürâtı îfầ ve menfa'at-i gayr-i meşrû'anın temini için vilayetleri ve civarı al kana boyamağa cür'et eyleyen mûmâileyh Sudi Efendi'nin de hemen Divan-ı Harbe teslimiyle cezâ-yı sezâsının (layık olduğu cezanın) bi't-ta'yîn, herhalde tekrar bir fesâd îkâ'ına meydan verilmemek üzere kat'iyyen bu havalîye gönderilmemesini selâmet-i vatan namına taleb ve istid'â eyleriz." Her iki telgrafın altına/arkasına "dosyasına/dosyası meyanına, hıfz" yazıldığı için mevcut bilgiler 1şığında Süleyman Sûdî Bey için Divan-1 Harp'te yargılanma diye bir olay söz konusu olmadığı söylenebilir. Çünkü Meclis-i Mebusan gündemine dokunulmazlığın kalkması için bir yazı gelmediği gibi, Dahiliye Nazırı Mehmet Talât Bey, Meclis-i Mebusan'daki tartışmalar esnasında valilerin Süleyman Sûdî Bey hakkında tahkikat yaptıklarını ancak kendisinin bu yönde bir emrinin olmadığını söylemiştir (MM.ZC., Devre: 1, İçtima Senesi: 2, İn'ikâd: 98, c. 5, s. 507).

Meclis-i Mebusan'ın 18 Mayıs 1910 (5 Mayıs 1326) tarihli toplantısında Posta, Telgraf ve Telefon Nezareti Bütçesi görüşülürken Posta ve Telgraf Müdür-i Umumi Vekili Fuat Bey'in açıklama yaptığı sırada ta'riz şeklinde, gönderilen mektuplarının açıldığını söylemişse de Fuat Bey bu iddiaları reddetmiştir. Ancak daha sonra söz alarak kürsüye gelen Süleyman Sûdî Bey; 22 Şubat 1910 (9 Şubat 1325) tarihinde ailesine ve dostlarına 11 mektup gönderdiğini, bu mektupların Erzurum Valisi tarafından açıldığını ve üç tanesinin de Dâhiliye Nezareti'ne gönderildiğini belirtmiştir. Bazı nasihatleri içeren bu mektupların açılması olayını Nezaretin dikkate almadığını savunan Süleyman Sûdî Bey, istibdat devrinde olsa çok görülmeyecek bu tür olayların Meşrutiyet döneminde meydana gelmesinin üzücü olduğunu, mektupların Meclise sunulması için konuyu gündeme getirdiğini belirtmiştir. Mektuplar üzerinde tahrifat yapıldığını ve kopya edilirken aynen aktarma yerine üzerinde oynamalar yapıldığını iddia eden Süleyman Sûdî Bey, "İkâra mecal yoktur. Meydanda olan şu mesele isbata kâfidir. Şu halde, demek oluyor ki, ya biz tehdit olunuruz veyahut sansür altına alınmak icap ediyorsak, bu babda Müdür izahat verdikten sonra ikame-i dava etmek üzere teşebbüs edeceğim" diyerek gerekli açıklama yapıldıktan sonra konuyu mahkemeye taşıyacağını söylemiştir. Mecliste konuyla ilgili açıklama yapan Posta, Telgraf ve Telefon Müdir-i Umumi Vekili Fuat Bey; bu konuyla ilgili olarak Müdüriyete herhangi bir şikâyetin gelmediğini belirttikten sonra bu tür kanunsuz işler yapanların cezalandırılacağını ifade etmiştir. Bazı mebusların konunun posta memuru veya valinin bireysel suçu olabileceği gerekçesiyle mahkemeye intikalini savunurken, Antalya Mebusu Mehmet Hamdi Efendi, Meclisin bu konuyu dikkate alması gerektiğini iddia etmiştir. Mektupların açılmasıyla ilgili herhangi bir karar alınmadan bütçe kabul edilmiş ve oturum sonlandırılmıştır (MM.ZC., Devre: 1, İçtima Senesi: 2, İn'ikâd: 92, c. 5, s. 306, 310-313).

Ancak; Posta, Telgraf ve Telefon Umum Müdür Vekili Fuat Bey'in açıklamalarından tatmin olmayan bazı mebuslar verdikleri takrirlerle konuyu Meclis gündeminden düşürmemeye çalışmışlardır. 19 Mayıs 1910 (6 Mayıs 1326) tarihinde; Ankara Mebusu Mahir Sait, Halep Mebusu Nâfi ve Bayezit Mebusu Süleyman Sûdî Bey ayrı ayrı verdikleri takrirle konuyu Meclis gündemine taşımışlar ve Dahiliye Nazırından izahat istemişlerdir. Konuyla ilgili olarak Mecliste açıklama yapan Dâhiliye Nazırı Mehmet Talât Bey; Meşrutiyet döneminde ve özellikle kendi nazırlığ döneminde mektup açmak gibi Kanun-1 Esasi'yi ihlal edecek hareketlerin kabul edilemeyeceğini belirttikten sonra Van ve Erzurum vilayetlerinden halkın başka yerlere göç ettiklerine dair iddialarla ilgili olarak Valilere emirler verildiğini anlatmıştır. Bunlara cevaben Erzurum Valisi'nden gelen bir telgrafta: Süleyman Sûdî Bey tarafından bu yönde bir söylenti yayıldığg ve konuyla ilgili olarak bir mektubun elde edildiğinden bahsedildiğini kaydeden Mehmet Talât Bey, kendisine de gönderilen mektubu okuduğunu ve içeriğinin suç teşkil etmediği için işlem yapılmadığını izah etmiştir. Bunun üzerine bazı mebusların söz atarak "mektubun nasıl 
elde edildiği, postanede mi açıldığı..." şeklindeki soruları üzerine, valilerin asayişi korumak için her türlü tedbiri almakla yükümlü olduklarını vurgulayan M. Talât Bey; karışıklık çıkarmak isteyenlere ait vesika ve delil bulan valilere "Bunları nasıl elde ettin?" diye sorulamayacağ şeklinde konuyu geçiştirmek istemiştir. Mektubun nasıl elde edildiğini net bir şekilde açıklamayan M. Talât Bey, tam tersine karşı atağa geçerek "mektubun Postahanede açıldığını iddia edenlerin (Süleyman Sûdî Bey vb.) bu iddialarını ispatla yükümlü olduklarını, ispat edemezlerse iftira atmış olacaklarını" savunmuştur. Mebusların 1srarlı müdahaleleri üzerine Valinin mektubu postanede açtırmadığını, ilgi şahsa teslim edildikten sonra elde edildiğini, dolayısıyla da Kanun-1 Esasi'nin ihlal edilmediğini iddia eden M. Talât Bey; bunun aksini iddia eden Süleyman Sûdî Bey'in Vali hakkında açılacak soruşturma sırasında iddialarını mahkemeye sunabileceğini ifade etmiştir. Bunun üzerine Vali hakkında asılsız iddia yaymış durumuna düşen Süleyman Sûdî Bey, defalarca söz istemişse de verilmeyince kürsüye çıkarak konuşmak istemiştir. Arbede sırasında Gümülcine Mebusu İsmail Hakkı Bey, Süleyman Sûdî Bey’i kürsüden uzaklaştırmıştır. Meclis Başkanının mebusların soru önergesinin cevaplandığını belirterek diğer gündem maddesine geçmek istemesi üzerine Süleyman Sûdî Bey (Bayezit), İsmail Hakkı Bey (Gümülcine) ve Nafi Paşa (Halep) Meclis Başkanlığına istizah takriri (gensoru önergesi) vermişlerdir. Süleyman Sûdî Bey takririnde; Erzurum Valisi Celal Bey tarafindan açılan mektuplar hakkında Meclisçe bir komisyon oluşturulması ve soruşturma açılmasını talep etmiştir. Bu takrirlerin gündeme alınıp alınmamasıyla ilgili tartışmalar sürerken Meclis Başkanı, şahsı ile ilgili ifadeler (asılsız iddiada bulunmak) nedeniyle Süleyman Sûdî Bey’e söz vermiştir. Kürsüye çıkarak Dahiliye Nazırı Talât Bey’e güveninin tam olduğunu belirten Süleyman Sûdî Bey; "mektuplarının bizzat Erzurum Valisinin açtığı" iddiasını sürdürmüş ve Meclis tarafından bir komisyon kurularak konunun soruşturulmasını istemiştir. Gönderilen 11 mektubun adrese teslim edilmeyerek Vali tarafından el konularak açıldığını iddia eden Süleyman Sûdî Bey; bu açılan mektuplardan sadece üçünün Nezarete gönderildiğini savunmuş ve kurulacak komisyonda bu iddialarını ispat edeceğini belirtmiştir. Bazı mebusların konunun Meclisçe oluşturulacak komisyon yerine mahkemede açıklığa kavuşturulmasına dair konuşmalarından sonra oturumu yöneten Meclis Başkanı; Süleyman Sûdî Bey'in komisyon kurulmasına dair önergesini oylamaya sunmuş ve bu öneri kabul edilmemiştir. Ancak aynı konuda Gümülcine Mebusu İsmail Hakkı Bey'in vermiş olduğu istizah takririnin (gensoru önergesi) gündeme alınması kabul edilmiştir (MM.ZC., Devre: 1, İçtima Senesi: 2, İn'ikâd: 93, c. 5, s. 329-333).

İsmail Hakkı Bey'in istizah takriri, Meclis-i Mebusan'ın 26 Mayıs 1910 tarihinde yapılan oturumunda görüşülmeye başlanmıştır. İstizah takriri (gensoru önergesi) ile ilgili olarak açıklama yapmak üzere kürsüye gelen Dâhiliye Nazırı Mehmet Talât Bey; Erzurum Valisinin gönderdiği evraktan, Süleyman Sûdî Bey'in yazdığı mektubun Bayezit'teki muhatabına ulaştığını, bundan sonra mektubun Erzurum Valiliğine gönderildiğini, iddia edildiği gibi Vali tarafından Erzurum'da postanede açılmadığını anlatmıştır. Bazı mebusların mektubu okuması yönündeki istekleri üzerine sahibi istemedikçe mektubu kürsüden okumayacağını belirten M. Talât Bey; işin idari boyutunun yanında hukuki boyutunun da bulunduğunu, Süleyman Sûdî Bey'in Vali hakkında dava açabileceğini, mektubun kimin tarafından Valiye gönderildiğini açıklamak zorunda olmadığını ve bu haliyle kendisine güvenoyu verilirse devam edeceğini, aksi takdirde görevden düşürülebileceğini ifade etmiştir. Takrir sahibi Gümülcine Mebusu İsmail Hakkı Bey söz alarak; Nâzırın " $\mathrm{Bu}$ mektubun postadan alınmadığına ben eminim, bana itimadınız varsa buna inanırsınız, eğer itimadınız yoksa, 1skat (görevden düşürmek) edersiniz" demek yerine istizah takririnde belirtilen konuda Meclise ikna edici deliller sunmasının gerekliliğin iddia etmiştir. Nâzırın zaten Mecliste çoğunluğa (İttihat ve Terakki) dayandığı için böyle davrandığını ve Meclise deliller sunmaktan kaçındığını savunan İsmail Hakkı Bey; mektup meselesinin "şahsi hak, içtimai hak ve siyasi hak" olmak üzere üç boyutunun bulunduğunu, şahsi hak boyutuyla ilgili olarak hakkı ihlal edilenin mahkemeye dava açabileceğini, haberleşmenin gizliliği hükmü bütün toplumu ilgilendirdiği için içtimai boyutu dolayısıyla Müddeiumuminin (savcı) dava açması gerektiğini, anayasal bir hakkın ihlali dolayısıyla konunun siyasi boyutu için Meclisin denetim yapması gerektiğini izah etmiştir. Meclisin bu denetim görevini yapmaması halinde her posta 
memurunun, mutasarrıfın veya valinin istediği mektubu açabileceğini iddia eden İsmail Hakk1 Bey; Nâzırın önerdiği gibi mahkemeye dava açılması yolunan gidilecek olursa mektup sahibinin mektubu valinin açtığına dair delil sunamayacağını ifade etmiştir. Sözlerinin devamında Nazırın "mektuplar sahibine ulaşıp açıldıktan sonra Bayezit'ten birinin bunları valiye gönderdiği" iddiasının doğru olmadığını belirten İsmail Hakkı Bey; mektuplardan birinin muhatabının Eleşkirt, birinin Karakilise (Ağrı) diğerinin Varsuva'da ikamet etmeleri ve bu üç yerin birbirinden çok uzakta olması nedeniyle bir kişi tarafından üç mektubun sahiplerine ulaşıp açıldıktan sonra elde edilip valiye göndermesinin inandırıcı olmadığını savunmuştur. Tam tersine, sahibine teslim edilmek için postaya teslim edilen bir mektubun Nâzırda bulunmasının mektubun sahiplerine teslim edilmeden Vali tarafından postaneden elde edilip açıldığının delili olduğunu savunan İsmail Hakkı Bey; Süleyman Sûdî Bey’e memleketteki akrabalarından Şubat-Nisan aylarında gönderilen üç mektupta, daha önceki mektuplara cevap verilmemesinden dolayı sitem edildiğini hatta bir mektupta "Sizin mektuplarınızı postahaneden kaldırıyorlar.....bu güne kadar gönderdiğiniz mektuplardan birçoğu Erzurum'da açıllyor" ifadelerinin bulunduğunu anlatmıştır (MM.ZC., Devre: 1, İçtima Senesi: 2, İn'ikâd: 98, c. 5, s. 494-497).

İddialara cevap vermek üzere kürsüye gelen ve Süleyman Sûdî Bey'in kendisine "Hasan (Hüseyin olmalı) Paşa'nın İran'a kaçmasından ${ }^{5}$ dolayı halkın endişe içinde bulunduğunu ve bölgeden göç etmekte olduğuna dair" başvurusu üzerine durum Erzurum ve Van vilayetlerinden sordurduğunu belirten Dahiliye Nâzırı Mehmet Talât Bey; gelen cevaplarda böyle bir durumun bulunmadığını, iddianın Süleyman Sûdî Bey'in vehminden kaynaklandığının anlatıldığını ve "galeyan halindeyiz, hicret etmek istiyoruz" şeklinde İstanbul'a gönderilen mektupların Süleyman Sûdî Bey'in teşviki ile yazdırıldığını anlatmıştır. Elde edilen mektupların sahiplerine ulaştıktan sonra birisi tarafından Valiye ulaştırıldığını savunan M. Talât Bey, ülkenin güvenliğini tehlikeye atan yazışmaları Valiye ulaştıran kişinin isminin açıklanmasının doğru olmayacağını belirtmiş ve bundan dolayı Meclis kendisine güvenmiyorsa görevden düşürebileceği sözünü tekrarlamıştır. Edirne Mebusu Rıza Tevfik de İsmail Hakkı Bey'i destekler bir konuşma yaparak anayasal hürriyetlerin ihlal edildiğini iddia etmesi üzerine tekrar kürsüye çıkan M. Talât Bey, Erzurum postasının bir çanta içinde Erzurum'a sevk edildiğini, çanta açıldıktan sonra da Bayezit postasının yine başka bir çanta içinde oraya gönderildiğini belirtmiştir. Her vatandaşın konut dokunulmazlığı ve haberleşmenin gizliliği haklarının bulunduğunu ifade eden Manastır Mebusu Trayan Nali Efendi ise; mustantığın (sorgu hakimi) kararı olmadıkça kimsenin konutuna girilemeyeceğini, mektuplarının açılamayacağını savunmuştur. Nazır M. Talât Bey'i destekler bir konuşma yapan Erzurum Mebusu Seyfullah Efendi; olayı duyduktan sonra Erzurum'da güvendiği kişilerle haberleştiğini ve olayın aslını araştırdığını, mektupların Erzurum'da postaneden alınmayıp, Bayezit'te sahiplerine ulaştıktan sonra valiliğe gönderildiğini tespit ettiğini ifade etmiştir. Erzurum Valisinin kanunlara aykırı bir muamelesi bulunmadığını savunan Seyfullah Efendi, Süleyman Sûdî Bey'in hakkını mahkemede aramasını tavsiye ve Meclis gündemine geçilmesini teklif etmiştir (MM.ZC., Devre: 1, İçtima Senesi: 2, İn'ikâd: 98, c. 5, s. 497-500).

Mektupların Vali tarafından açıldı̆̆ı iddialarını saçma bulan Hüseyin Cahit Bey (İstanbul), Nazırın ifadesine mektupların içeriğinin önemli olduğunu, mektup sahiplerinin madden olmasa bile, manen halk arasında fitne çıkması suçuna ortak olduklarını savunmuştur. Bunun üzerine kürsüye çıkmadan söz alan Nazaret Dagavaryan Efendi (Sivas) mektupların içeriğinin kürsüden okunmasını talep etmiştir. Nazır ve Hüseyin Cahit Bey gibi bazı mebusların mahkemeye dava açmaları yönündeki sözlerini doğru bulmayan Lüfti Fikri Bey (Dersim); Vali hakkında dava açılabilmesi için Nezaretten izin ve irade-i seniyye alınması gerektiğini,

\footnotetext{
5 Hamidiye Hafif Süvari Alaylarından birisinin kumandanı olan Heyderan/Haydaran Aşiret Reisi "Kör" lakabıyla bilinen Hüseyin Paşa, İttihat ve Terakki'nin alayları düzenli orduya bağlama çalışmaları nedeniyle İttihatçılara mesafeli durmuştur. II. Meşrutiyetin İlanı'ndan sonra 1908 yılında bazı aşiret reisleriyle birlikte tutuklanan Hüseyin Paşa, hapisten çıtıktan sonra alaylarıyla birlikte 1910 yılında İran'a geçmiştir. İstanbul'a çektiği telgraflarda Erzurum Valisinden eziyet gördüğü için kaçmak zorunda kaldığını belirtmiștir. Hükümet, Hüseyin Paşa'ya bir ay süre vererek, yurda dönmediği takdirde Divan-1 Harpte yargılanacağı, rütbe ve nişanlarının alınacağını bildirmiştir. Bunun üzerine yurda dönen Hüseyin Paşa, Van Valisi tarafından karşılanmış ve Van'da zorunlu ikamete mecbur edilmiştir. Bkz: Makul Yıldırım, II. Meşrutiyet Dönemi n’’e Bayezit Sancağı (1908-1918), Ağrı İbrahim Çeçen Üniversitesi, Sosyal Bilimler Enstitüsü Yayınlanmamış Yüksek Lisans Tezi, Ağrı, 2018, s. 115-121.
} 
dolayısıyla böyle bir işlemin işi baştan savmak olduğunu, mektupların kimin tarafindan açıldığı konusunda Süleyman Sûdî Bey'in değil Hükümetin ispatla yükümlü olduğunu savunmuştur. Prusya ve Avusturya anayasalarından örnekler vererek, mektupların sahibinin eline geçmeden açılmasının suç olduğunu ileri süren Lütfi Fikri Bey; keyfi yönetimlerin aksine Meşrutiyet Hükümetlerinde Nâzırın "Devletin güvenliği için mektupları takip ettim ve elde ettim, kimden elde ettiğimi sormayın.” şeklinde bir ifadesinin doğru olmadığını, Valinin kendine başkası tarafından gönderilmiş olsa bile mektupları açmak yerine başka yöntemlerle suçu/suçluyu takip edip, zaptiyeler göndererek mektubun muhataplarının evlerinin aratılmasını istemesinin kanuna daha uygun olacağını savunmuştur. İddialara cevap veren Dahiliye Nazırı Mehmet Talât Bey; Lütfi Fikri Bey'i başka ülkelerin anayasalarını bildiği halde Kanun-1 Esasi'yi iyi bilmemekle suçlamış ve mektupların açılması konusunun Valinin göreviyle ilgili bir suç olsaydı onu azledeceğini, ancak bu suçun "cürmü âdî: sıradan, kişisel bir suç" olması nedeniyle mahkemeye dava açılması gerektiğini ifade etmiştir. Nazır Mehmet Talât Bey konuşmasının devamında, Süleyman Sûdî Bey'in başvuruları nedeniyle halkın galeyanıyla ilgili valilerin dikkatinin çekilmesi yönünde vilayetlere tebligat yapıldığını ve bundan dolayı Süleyman Sûdî Bey’e karşı bir hassasiyetin oluştuğunu şu sözlerle kabul etmiştir: "Buyuruyorlar ki Valilerin nazar-ı dikkati celb edilmiş, Süleyman Sûdî Efendi'ye karşı onlarda bir hırs-ı intikam olmuş. Bundan dolayı Süleyman Sûdî Efendi hakkında tamîkî tahkikata (detaylı araştırma) lüzum görülmüss. Bunlar mahrem değildir, bunlart söyleyebilirim. Ícab ederse, cereyan eden evrakı muhabereyi de Meclise gösterebilirim (...) Her memlekette olduğu gibi bizim memleketimizde de Kanun-ı Esaside mektupların mahremiyeti, masuniyeti mezkûrdur (gizliliği ve korunması zikredilmiştir)(...) Kanunu Esasimiz de o taarruzdan bizi men ediyor. Biz de o mektuplarin mahremiyetine riayet ettik, neşretmedik. Hatta Süleyman Sûdî Efendinin kendisinden maada hiçbir ferde mektupları göstermedir” (MM.ZC., Devre: 1, İçtima Senesi: 2, İn'ikâd: 98, c. 5, s. 500-507).

Tartışmaların uzaması üzerine Süleyman Sûdî Bey mektuplarının Meclis kürsüsünden okunmasını talep etmiş ve Meclis Başkanı da Süleyman Sûdî Bey tarafından yazılan mektupları okutturmuştur. Okunan ilk mektubunda, İran'a kaçmış olan Hüseyin Paşa'nın iade ettirilmesi için birçok makama başvuruda bulunduğunu ve bunun için emir verildiğini ifade eden Süleyman Sûdî Bey; Tercüman-1 Hakikat'in 29 Kanunusani 1325 tarihli nüshasında aşiretlerle ilgili bir makale* yazdığını, gazete Karakilise'ye ulaştığında okunup mütalaa edilmesini, aşiretler birbirine bağlı olsa o tarihe kadar binlerle telgraf çekileceğini, ancak bu bağ olmadığı için hiçbir taraftan ses çıkmadığını ifade etmektedir. "Hayvan gibi sükut ile vakit geçiriyorlar" şeklinde ağır bir eleştiriyi de dile getiren Süleyman Sûdî Bey; aşiretlerin ileride kötü olaylarla karşılaşmaktan korktuklarına ve Müslüman aşiretlerin heyecan içinde olduklarına dair kendisine mektuplar yazılmasını ve bu mektuplarda aşiretlerin baharın İran ve Rusya'ya göç edeceklerinden bahsedilmesini istemiştir. 9 Şubat 1325 tarihli ikinci mektubunda, Hacı Emin Efendi ve diğer tanıdıklara konunun iyice anlatılmasını isteyen Süleyman Sûdî Bey, "Beher hafta birçok mektup yazsınlar. Mesele sırf Hüseyin Paşa'dan ve aşâirin galeyana gelip Iran'a ve Rusya'ya gideceklerinden ve şu halde nüfus-u İslâmiyenin taklîl (azalma) olunmasından bahsedilmelidir. Öyle birçoklarına ve lâzım gelenlere tefhimi müsterhamdır. Hukuklarını muhafaza etmezlerse bendeniz ne yapayım?" şeklinde sitemini de dile getirmiştir. Aynı tarihli bir diğer mektubunda, Tercüman-1 Hakikat’teki makalesinden bahseden Süleyman Sûdî Bey, kendi girişimleri sonucunda Dâhiliye ve Harbiye

\footnotetext{
* Süleyman Sûdî Bey bu makalesinde özetle şu hususlara değinmiştir: Makalenin yazılma nedeni Hüseyin Paşa'nın şahsı veya olumlu/olumsuz icraatları değildir. İran ve Rusya ile sınır olan Erzurum Vilayeti halkının büyük çoğunluğu aşiretlerden meydana gelmektedir ve bu aşiretler Halifeye ve meşrutiyete bağlıdırlar. Ancak bir kısmı idarecilerin yanlış icraatları nedeniyle bölgeyi terk ederek yurtdışına gö̧̧müşlerdir. Bu göçlerle bölge nüfusunun azalması ve nüfus dengesinin bozulması gelecekte büyük zararlara yol açacaktır. Hüseyin Paşa'nın İran'a gitmesi ve bazı aşiretlerin de göç için hazırlanmaları ülke için tehlikelidir. Meşrutiyete bağlı olan halkı bazı idarecilerin kötü icraatlarının rahatsız etmesi kabul edilemez. Bu durum devletin geleceği için olumsuz sonuçlar doğuracaktır. Hüseyin Paşa vesaireyi İran'a gitmeğe mecbur etmek ve bazı aşiretlerin de gitmesine çı̆̆ır açmak devlet yönetimi anlayışı ile bağdaşmaz ve halk arasında nifak tohumları ekilmesine neden olur. Hüseyin Paşa'nın devlet mallarından zimmetine geçirdiği parayı iç etmek için İran'a gittiği iddiaları doğru değildir. Bu adam zulüm görmüş ve adaletle yargılanmak için kendisi başvuru yapmıştır. Meşrutiyet ve istikbali temin edecek hallerin araştırılması ve cins ve mezhep ayırımı yapılmaksızın halka adaletli davranılması gerekir. Bu konuda yetkililerin dikkati çekilmek istenmiştir. Bkz: Tercüman-ı Hakîkat, No: 10366 (29 Kanunusani 1325/11 Subat 1910), s.1.
} 
Nezaretlerinden Hüseyin Paşa'nın getirtilmesi için emirler verildiğini, ancak așiretlerden bu konuda hiç ses çıkmadığını şu ifadelerle kaydetmektedir: "Aşâirin hamâkatı malumdur. Yekdiğeri aleyhinde olsa idi şimdiye kadar binlerle telgraf ve istida gönderirlerdi. Hayvancasina sükût etmişlerdir. Hele mürâcaat yok, bari hiç olmazsa bendenize yazsınlar, aşiretlerin galeyanını bildirsinler. Onların mektupların makama ibraz ve takdim edeyim ve çaresini istihsal edeyim (...) Umum aşâir müttehit olmalıdır. Şâyet mürâcaat etmez ve yazmazlarsa artık kendileri bilirler (...) Erzurum Valisi gibi bir ahmağın bed (kötü) muamelesine yüz binlerle ehl-i İslâm mahvolacaktır.", (MM.ZC., Devre: 1, İçtima Senesi: 2, İn'ikâd: 98, c. 5, s. 510-512).

Mektuplar okunduktan sonra kürsüye çıkan Süleyman Sûdî Bey; Şubat ayında birçok kişiye* mektup yazdığını, II. Abdülhamid devrinde Hüseyin Paşa gibi kişilerle hiçbir münasebetinin bulunmadığını ve haberleşmediğini, Erzurum Valisinin kötü idaresinden dolayı bazı aşiretlerin İran'a gittiklerini, kendisine, Hakkâri'den Taha Efendi ve Tevfik Bey'e, Genç Mebusu Mehmet Bey'e gelen mektuplarda halkın göç etmek niyetinde olduğunun yazıldığını ifade etmiştir. Dördüncü Ordu Müşirliğinden yazılan yazıda da bu göç arzusunun teyit edildiğini vurgulayan Süleyman Sûdî Bey, meselenin Hüseyin Paşa'nın şahsı ile ilgili olmadığını, mektup yazdığı kişilerden bir kısmının İttihat ve Terakki’ye mensup kişiler olduğunu belirttikten sonra mektup açmanın Anayasanın ihlâli olduğunu savunmuştur. Mektuplaştığı kişiler arasında İttihatçıların da bulunduğunu vurgulayan Süleyman Sûdî Bey, yukarıda özeti verilen ve Mecliste okunan mektuplarındaki kayıtların aksine aşiretlerle haberleşmediğini, Ermeni murahhasalığı, belediye ve sancak yöneticileri ile yazışmalarında kendisinin meşrutiyetçi ve vatan ve millet için çalıştığının görüleceğini iddia etmiştir. Varteks Efendi'nin iddialarının aksine Bayezit Sancağı'ndaki Ermeniler ve Müslümanlar arasında ciddi bir sorun bulunmadığını anlatan Süleyman Sûdî Bey; Hüseyin Paşa'nın İran'a gitmesinin de Ermenilerle ilgili olmayıp İdmanlı Aşireti ile Hüseyin Paşa'nın mensubu bulunduğu Haydaranlı Aşireti arasındaki arazi anlaşmazlıklarından ve Valinin kötü davranmasından kaynaklandığını ve bu kişinin geri getirilmesinin ülke menfaatleri açısından yararlı olacağını savunmuştur. Karakilise Başkâtib-i Sâbıkı Şâmil imzasıyla 1 Şubat 1325 tarihli ve Meclis-i İdare Âzâsı Şâkir imzalı 11 Şubat 1325 tarihli iki mektubu da okuyan Süleyman Sûdî Bey, bu ve benzeri mektuplarda halkın galeyan içinde bulunduğu, Hüseyin Paşa'nın affedilerek geri getirilmesi gerektiği, Valinin Hüseyin Paşa ve diğer bazı kişilere karşı olumsuz tavırlarının neler olduğunu anlatmıştır. Van Mebusu Tevfik Bey'e gelen kendisine tevdi edilen mektupta Van Valisinin kötü idaresinden bahseden Süleyman Sûdî Bey; Ali Kadri Bey'e yazdığı mektubun da Vali tarafından alındığını, Bayezit Müdde-i Umumisi (savcı) Nâzım Bey'in Arif Fazıl Efendi’ye yazdığı mektupta "Erzurum Valisi Celâl Bey'in jurnalcilik yaptığından" bahsedildiğini örnek göstermiştir. Erzurum Valisi Celâl Bey’in kötü yönetimi dolayısıyla ilgili olarak bazı makamlara başvurularda bulunduğu için bu olayların yaşandığııı iddia eden Süleyman Sûdî Bey; mektupların nasıl alındığının açıklanmamasını devri sâbık (II. Abdülhamit Dönemi) anlayışı olarak nitelendirdikten sonra Varto, Karakilise ve Eleşkirt'e gönderilen mektupların toplanarak Valiye teslim edilmesinin mantıklı bir tarafının bulunmadığını savunmuş ve Şura-yı Devlet'te de dava açacağını belirterek sözlerini tamamlamıştır. Bu konuşmadan sonra Meclis Başkanı müzakerenin yeterli olup olmadığını oylamaya sunmuş ve kabul edilmiştir. Menteşe Mebusu Halil Bey'in "Süleyman Sûdî Bey'in mektuplarının açılmasıyla ilgili izahatının yeterli bulunarak Dâhiliye Nâzırına güvenoyu verilmesine" dair önergesi oylanmıştır. Yapılan oylamada (Gümülcineli İsmail Hakkı ve Süleyman Sûdî Bey dahil) 32 güvensizlik oyuna karşılık 141 güvenoyu ile Dâhiliye Nâzırı Mehmet Talât Bey’e güvenoyu verilmiştir (13 Mayıs 1326/26 Mayıs 1910) ${ }^{6}$. Böylece; Süleyman

\footnotetext{
* Süleyman Sûdî Bey'in mektup yazdığını belirttiği kişiler şunlardır: İttihat ve Terakki Hey’et-i İdaresinden Mülâzım Cemal Efendi, Mülâzım Mehmet Behlül Efendi, Yusuf Çavuş, Tahir Efendi, Karakilise Hey’et-i İdaresi Âzâsından Ali Kadri Efendi, Mehmet Rıfat Efendi, Şâkir Efendi, Erzurum'da Bayezit Meclis-i Âzâsından Mustafa Efendi, Yusuf Efendi. Bkz: MM.ZC., Devre: 1, İçtima Senesi: 2, İn'ikâd: 98, c. 5, s. 512.

${ }^{6}$ MM.ZC., Devre: 1, İçtima Senesi: 2, İn'ikâd: 98, c. 5, s. 512-516, 524-525. Güven oylamasının sonucu, 13 Mayıs 1326 (26 Mayıs 1910) tarihli bir telgrafla Erzurum Valiliği'ne bildirilmiştir. Vali Celal Bey de bir gün sonra gönderdiği cevabi telgraf metninde "Muhafaza-i hakk ve adl emrinde vâki' olan lütuf ve inayetlerinden dolayı arz-1 şükran eyler ve muvaffakiyet-i vâkı'a sebebiyle zât-1 Sâmîlerini tebriğe mücaseret eylerim.” ifadelerine yer vermiştir. Bkz: BOA. DH. MUI. D: 78, G: 66, V: 7, 9, 10.
} 
Sûdî Bey’in mektuplarının açılmasıyla ilgili olarak komisyon kurulması öneri kabul görmediği gibi bu konuyla ilgili Meclis-i Mebusan boyutu tamamlanmıştır. Süleyman Sûdî Bey ve muhalefet sonuç alamamıştır.

Meclis-i Mebusan'daki tartışmalar esnasında mektuplarının açılmasıyla ilgili olarak mahkemede dava açacağını söyleyen Süleyman Sûdî Bey'in bu konuda dava açıp-açmadığı mevcut bilgiler ışığında tespit edilememektedir. Bazı muhalif mebusların da ifade ettikleri gibi mektupları valinin açtığının ispatı oldukça zor olduğu için mahkemeden sonuç alınamayacağ düşüncesiyle Süleyman Sûdî Bey dava açmamış da olabilir. Diğer taraftan; muhalefetin, olayın sorumlusu olarak nitelendirdiği Erzurum Valisi Mehmed Celal(eddin) Bey, daha prestijli görevlere gelmiş hatta Nazırlık bile yapmıştır ${ }^{7}$.

\section{Süleyman Sûdî Bey'in İttihat Terakki'den Ayrılarak Ahali Fırkası'na Katılması}

İttihat ve Terakki Cemiyeti içinde yer alan Süleyman Sûdî Bey, Meclis-i Mebusan'a bu cemiyet mebusu olarak girmiştir. Ancak İttihat ve Terakki Fırkası yönetimi ile yaşanan görüş ayrılıkları bir bölünme ile sonuçlanacaktır. Neticede İsmail Hakkı (Gümülcine), Vasfi (Karesi), Ferhad (Trablusgarp), Şevket (Erzurum), Ömer Lûtfi (Burdur) Beylerle birlikte Süleyman Sûdî Bey de İttihat ve Terakki'den istifa ederek Ahali Furkası'nı kurmuşlardır (8 Şubat 1325/ 21 Şubat1910). 1911 yılına kadar Meclis'te bazı konularda etkisini göstermeye çalışan bu Firka ülke çapında geniş bir teşkilata da kavuşamamış ve 1911 yılında kurulan Hürriyet ve İtilaf Fırkası'na katılmıştır (Tunaya, 1988: 234-245). Süleyman Sûdî Bey'in mektupların açılması konusu bu Fırkanın Meclis'te kendini ispat etmeye çalıştığı olaylardan birisi olmuştur. Bununla ilgili takrir veren üç isim (Süleyman Sûdî, İsmail Hakkı Bey (Gümülcine) ve Nafi Paşa (Halep)) bu firka mensubu mebuslardır. Yani mektupların açılması meselesi, muhalefetin bir bakıma İttihat Terakki iktidarına karşı bir eleştiri konusuna dönüştürülmüştür.

İttihat ve Terakki'den bu mebusların istifası, ülke içinde bir suçlama ve karalama kampanyasına (Tunaya, 1988: 238-245) dönüşmüştür. Bu çerçevede taşradaki İttihat ve Terakki kulüpleri/şubeleri veya mensupları tarafında yazılan telgraf ve mektuplar yerel ve ulusal gazetelerde yayınlanmıştır. Örneğin; Erzurum Belediye Reisi Şerif Bey tarafindan İstanbul gazetelerinde ağır ifadeleri içeren bir mektup yayınlanmıştır. Buna karşılık Tekirdağ'dan postaya verilen A(yın) ve N(un) imzalı tehdit ve hakaret içeren bir mektup Erzurum Valiliği, Dahiliye Nezareti ve Tekfurdağı (Tekirdağ) Mutasarrıflığı hakkında yazışmalara neden olmuştur (BOA. DH. MUİ. D: 78, G: 66, V: 2-5, 8). İşte bu aşamada Süleyman Sûdî Bey, İttihat ve Terakki'den neden ayrıldıklarına ve yeni firkanın politikalarına dair 22 Şubat 1325 (7 Mart 1910) tarihli Yeni Gazete'de bir mektup yayınlamıştır. Surf İttihat ve Terakki Cemiyeti üyelerinden oluşmayan ve herhangi bir yemine ve kayda bağlı olmayan İttihat ve Terakki Firkası'ndan istifa ederek Ahali Fırkası'nı kuranlar hakkında gazetelerde yer alan iddia ve ithamlara cevap vermek amaciyla bu mektubu yazdığını belirten Süleyman Sûdî Bey; memleketi yıllardır süren istibdattan kurtaran ve meşrutiyetin nigâhban-1 mukaddesi (kutsal bekçisi) olan Osmanlı İttihat ve Terakkî Cemiyeti'ne bağlı olduğunu vurgulamıştır. Kendisi ve Ahali Fırkası'nı kuran diğer mebusların İttihat ve Terakki Fırkası'nın hilafgîri (muhalifi) olmadıklarını savunan Süleyman Sûdî Bey; çoğu konuda İttihat ve Terakki'yle aynı şeyleri savunmakla beraber, vicdanlarının kabul etmediği bazı hususlarda özgürlüğü korumak amacını güttüklerini ifade etmiştir. Hürriyet ve Meşrutiyetin sonsuza kadar bir müntesibi olduğunu ve bunun için hürriyet ve vicdan özgürlüğünü savunmaktan çekinmeyeceğini belirten Süleyman Sûdî Bey; vatanın refah içinde ve medeni bir hayat sürmesini,

\footnotetext{
7 Mehmed Celâl (gerçek adıyla Mehmed Celâleddin) Bey, 1863 yılında İstanbul'da doğmuş, 1883 yılında Mülkiye Mektebi'nin Yüksek Kısmı'ndan mezun olmuştur. Ziraat tahsili için Almanya'ya gönderilen Mehmed Celâl Bey; Dârülmuallimîn de dâhil olmak üzere çeşitli okullarda Coğrafya muallimliği yaptıktan sonra Dârülfünûn'da Coğrafya Müderrisliği (profesörlük) görevini yürütmüștür. 1908'de Mülkiye Mektebi Müdürlüğü'ne atanan Mehmed Celâl Bey daha sonra idareciliğe geçmiş 5 Haziran 1909'da Erzurum Valiliği görevine tayin edilmiştir. 1911 yılında buradan Edirne Valiliği'ne atanan Mehmed Celâl Bey; Dâhiliye Nâzırlığı, İzmir Valiliği, Ticaret ve Ziraat Nazırlığı, Halep, Konya ve Adana Valiliği ve İstanbul Şehreminliği görevlerinde bulunmuştur. Cumhuriyetin İlanı'ndan sonra İstanbul Reji Başmüdürlügü̈ne getirilen Mehmed Celâl Bey bu görevi sırasında 1926 yılında vefat etmiştir. Bkz: Mücellidoğlu Ali Çankaya, Son Asır Türk Târihinin Önemli Olayları ile Birlikte Yeni Mülkiye Târihi ve Mülkiyeliler, c. 2, Mars Matbaası, Ankara, 1968-1969, s. 831-833.
} 
halkın saadet ve selametini meşruti idareden beklediği bir dönemde mebusların hareketlerinin kısıtlanmasını, aklıselim sahibi herkesin üzüntü ile karşılaması gerektiğini iddia etmiştir. Dünya üzerinde meşrutiyetin ilan edildiği ülkelerin meclislerinde partilerin kurulduğunu ve böylece siyasi özgürlüklerin gerçekleştirildiğini kaydeden Süleyman Sûdî Bey, "(barika-i) hakikat müsademe-i efkârdan çıkar" sözü hikmetli bir düstur olarak ortada iken, farklı partilerin kurulmasını yersiz bulanların meşrutiyet idaresini anlamadıklarını veya hastalıklı düşünce sahipleri olduğunu iddia etmiştir. Meşrutiyetin İlanı ile İttihat ve Terakki'nin vatana çok büyük hizmet ettiğini belirten Süleyman Sûdî Bey, İTC ile İTF'nı ayrı tüzel kişilik olarak görmüş ve hürriyeti seven her vatanperverin Mecliste kurulan İttihat ve Terakki Fırkası'na muhalif olsa bile kutsal bir kuruluş olan İttihat ve Terakki Cemiyeti tarafından takdir edilmesi gerektiğini savunmuştur. Kişisel çıkarlarını halkın menfaatlerine zarar vermekte arayan bazı alçak yaratılışlı kişiler müstesna olmak üzere bütün Osmanlıların vatan ve milletin saadet ve selametini sağlayacak olan Meşrutiyet idaresine bağlı olduklarını vurgulayan Süleyman Sûdî Bey; tanımadığ 1 ve mebus seçilmesinde hiç etkisi olmayan yerlerden gönderilen telgraflarda isminin geçtiğini, bu hakaret içeren telgrafların gazetelerde yayınlandığını belirtmiştir. Bu telgrafların aksine kendi seçim bölgesi olan Bayezit Sancağı müntehib-i evvel ve müntehib-i sanilerinden (birinci ve ikinci seçmen) gelen telgraflarda, mebusluktan istifa ettiği yönündeki haberlerden duyulan üzüntünün yer aldığını ifade eden Süleyman Sûdî Bey; aleyhteki eleştiri ve telgrafların son bulmasını vatan ve milletin selameti için gerekli görmüş ve mektubunu, Bayezit'ten gönderilen ve Tahir, Cemal, Mustafa, Abdullah, Yusuf ve Mehmet imzalı destek telgrafinın metni ile sona erdirmiştir(Süleyman Sûdî, "Fırkalar Dolayısıyla", Yeni Gazete, No: 549 (22 Şubat 1325/7 Mart 1910), s. 2).

Süleyman Sûdî Bey'in yukarıda özetlenen mektubundan da anlaşılacağı üzere; Ahali Fırkası'nı kuran mebuslar, İttihat ve Terakki Cemiyeti ile Mecliste oluşturulan İttihat ve Terakki Fırkası'nı farklı kurumsal yapı olarak değerlendirmekte ve Meşrutiyetin İlanını sağlayan İTC'ne bağlı kalmakla birlikte, o cemiyetin Meclisteki temsilcisi olan İTF'ndan istifa etmişlerdir. II. Meşrutiyet'in başlangıcında tam olmasa da iktidarı temsil eden İTF'nın da bütün kararlarına muhalefet etmeyen Gümülcineli İsmail Hakkı ve beraberindekiler, Mecliste parti grubu şeklinde disiplin içinde hareket edilmesi yönündeki eğilime karşı akıl ve vicdanlarına uymayan konularda ITF'ndan ayrı hareket edebilmeyi tercih etmişlerdir. Yani her konuda firka yönetimine tam itaat ilkesine karşı gelmekle birlikte iktidarı temsil eden ITTF'nın bütün politikalarına körü körüne muhalefet etmeye de taraftar değildirler.

Süleyman Sûdî Bey'in Ahali Fırkası'na geçmesi, Bayezit Sancağı'nda kısmen tepki ile karşılanmıştır. Bayezit'a gitmek üzere Erzurum'a gelen Süleyman Sûdî Bey’e karşı olumsuz hareketler yaşanmıştır. Erzurum Valisi Celal Bey'in Nezarete gönderdiği telgrafta; daha kötü olayların yaşanması İttihat ve Terakki Cemiyeti'nin Erzurum Şube yönetiminin gayretleri ile güçlükle engellenebilmiştir. Süleyman Sûdî Bey, Karakilise'de İTF'ndan neden ayrıldıklarını ve Ahali Fırkası'nın programını anlatmak için bir konferans vermek istemişse de halk tarafından konuşma yapmasına mani olunmuş ve orayı terk etmeye zorlanmıştır. Celal Bey telgrafin devamında; Süleyman Sûdî Bey'in Kürt aşiret reislerine yayladan inmemeleri yönünde mektuplar yazdığını, Karakilise'ye geldiğinde görüştüğü bazı aşiret reislerini, daha önce yazdığı mektuplardaki tavsiyelerine (İstanbul'a telgraf çekilmesi ve mektup gönderilmesi) uymadıkları için azarladığını belirtmekte ve Süleyman Sûdî Bey'in olumsuz girişimlerine karşı her türlü tedbirin alındığ ifade edilmektedir (12 Ağustos 1910) (BOA. DH. MUİ. D: 72, G: 79, V: 3).

Süleyman Sûdî Bey 1912 y1lında yapılan seçimleri de kazanarak İkinci Meşrutiyet dönemindeki Meclis-i Mebusan'ın ikinci döneminde de Bayezit mebusu olarak görev yapmıştır. 12 Mayıs 1328 (25 Mayıs 1912) tarihinde Meclis çalışmalarına katılan Süleyman Sûdî Bey, 18 Nisan 1912 - 5 Ağustos 1912 tarihleri arasında kısa süre görev yapan ve feshedilen Meclis-i Mebusan'ın yasama faaliyetlerinde görev almıştır. (MM.ZC. Devre: 2, c. 1, İn'ikad: 7, s. 90; MM.ZC. Devre: 2, c. 1, İn'ikad: 15, s. 335; MM.ZC. Devre: 2, c. 1, İn'ikad: 23, s. 564; MM.ZC. Devre: 2, c. 2, İn'ikad: 26, s. 48-64). 
Süleyman Sûdî Bey 1914 yılında yapılan Meclis-i Mebusan seçimlerinde de aday olmuşsa da seçilememiştir. Seçimlerde usulsüzlük yapıldığına dair Erzurum Valiliği’ne ve Dahiliye Nezareti'ne başvurularda bulunmuştur. Erzurum Valisi Reşid imzasıyla 19 Mart 1914 tarihinde Nezarete gönderilen telgrafta; Süleyman Sûdî Bey'in iddia ettiği gibi seçimleri etkileyecek olayların yaşanmadığı, tartışma ve şamata şeklinde yaşanan olayın faillerinin Adliyeye sevk edildiği ve olaylarla ilgili Süleyman Sûdî Bey'in elinde bulanan evrakın teslim alınması için Karakilise Kaymakamlığı'na emir verildiği belirtilmiştir (BOA. DH. ŞFR. D: 422, G: 55, V: 1-3). Süleyman Sûdî Bey'in bu seçimlerde başarılı olamamasının sebepleri arasında, muhalif firkaya geçmiş olmasını da saymak gerekir.

\section{Süleyman Sûdî Bey'in I. TBMM'ndeki Faaliyetleri}

Misak-1 Milli kararının alınmasını cezalandırmak isteyen İtilaf Devletlerinin 16 Mart 1920 günü İstanbul'u resmen işgal etmeleri, devlet kurumlarını kontrol altına almaları ve hatta Meclis-i Mebusan binasını kuşatarak bazı mebusların tutuklanması üzerine Meclisin tatili gündeme gelmiştir. Bolu Mebusu Tunalı Hilmi Bey ve arkadaşları, uygun şartlar oluşuncaya kadar Meclis-i Mebusan toplantılarının ertelenmesine dair Meclis Başkanlığına bir önerge vermişlerdir. Önergenin oy birliği ile kabul edilmesiyle Meclis-i Mebusan toplantıları tatil edilmiştir (18 Mart 1920) (MM.ZC., Devre: 4, c. 1, İn'ikâd: 24, s. 494-497). Bunun üzerine Heyeti Temsiliye Reisi Mustafa Kemal Paşa, 19 Mart 1920 tarihinde yayınlamış olduğu seçim genelgesiyle, Ankara'da olağanüstü yetkilere sahip bir meclis toplanacağını bildirmiş ve bu meclis için her sancaktan beşer üye seçilerek Ankara'ya gönderilmesini istemiştir. Bu genelgenin uygulanması çerçevesinde seçilip de Ankara'ya gelebilen mebusların katılımıyla 23 Nisan 1920 tarihinde Büyük Millet Meclisi çalışmalarına başlamıştır (Atatürk, 1994: 266-268; Türkiye Büyük Millet Meclisi Zabit Ceridesi*, Devre: 1, c. 1, s. 1-2).

Süleyman Sûdî Bey'in I. TBMM için mebus seçildiğine dair mazbatada şu ifadeler yer almaktadır: "Meclis-i Meb'ûsânımızın ifâ-yı vazife edemeyeceğini resmen Hükümete tebliğ ederek dă̆ılması ve Makarr-ı Hilâfet-i İslâmiyenin (İslam Halifeliğinin merkezi) işgal olunması üzerine rahne-dâr olan kuvve-i teşrî'iye ve adliye ve icrâ'iyeden (yasama, adalet ve yürütme gücü) ibaret kuvâ-yı temsiliye-i devletin (devletin temsil güçlerinin) muhafazası ve işgal altındaki eczâ-yl vatanin istihlâsl ve Millet-i İslâmiyenin te'mîn-i sa'âdeti azm-i kavisiyle (güçlü azmiyle) Ankara'da küşâd olunan (açılan) Büyük (Millet) Meclisi azalığına Erzurum Vilâyeti'nin Bayezit Livâsı nâmına Bayezit Mebus-ı Esbakı (eski mebusu) Süleyman Sûdî Efendi'nin seksen bir re’y ile ihrâz-ı ekseriyet (çoğunluğun sağlanmas1) eylemiş olduğuna mebni işbu mazbata tanzim ve yed-i mûmâ 'ileyhe i'tâ kalındı (düzenlenerek onun eline verildi)". İstanbul'un işgali, Meclisin tatil edilmesi nedeniyle Ankara'da toplanacak Millet Meclisi için 81 oy alan Süleyman Sûdî Bey'in diğer dört kişi ile birlikte mebus seçildikleri belirtilen mazbatada Süleyman Sûdî Bey'in 15 Mayıs'ta Meclise katıldıklar1 kaydedilmektedir (https://www.tbmm.gov.tr/eyayin /GAZETELER/WEB/MAZBATALAR/TBMM/d01/SM_47_1_1.pdf). Süleyman Sûdî Bey'in mebus seçimine dair mazbatası 15 Mayıs 1920 tarihinde Mazbataları Tetkik Encümenince uygun bulunduktan sonra Meclis Genel Kurulu'nun 15 Temmuz 1920 tarihinde onaylanmıştır (TBMM.ZC., Devre: 1, c. 2, s. 333).

Süleyman Sûdî Bey'in ilgilendiği ve sonuca ulaştırdığı önemli yasama faaliyetlerinden birisi "Bayezit'ın Müstakil Liva Haline Ifrâğına" dair teklifidir. Erzurum Vilayeti'ne bağlı bir sancak olan Bayezit Livası'nın bağımsız sancak olarak Dâhiliye Vekâleti'ne doğrudan bağlanması, idari açıdan oldukça önemli kolaylıklar sağlayacaktı. Aslında bu konu daha önce, 1909 yılında da gündeme gelmiş ise de Erzurum Valiliği'nin itirazları neticesinde bu gerçekleşememiştir (Yıldırım, 2018: 45). Süleyman Sûdî Bey'in bu konudaki kanun teklifi, TBMM'nin 24 Temmuz 1920 tarihinde tarihli toplantısında duyurulmuş ve Lâyiha Encümeni'ne havale edilmiştir (TBMM.ZC., Devre: 1, c. 2, s. 381). Süleyman Sûdî Bey'in yanı sıra aynı konudaki Rüştü ve Mehmet Naci Beylerin kanun teklifleri Lâyiha Encümeni'nce birleştirilerek

\footnotetext{
* Türkiye Büyük Millet Meclisi Zabıt Ceridesi İsimli Eser bundan sonra "TBMM.ZC." şeklinde kısaltılarak verilecektir.
} 
Meclis Genel Kuruluna sunulmuştur. Lâyiha Encümeninin mazbatası Meclisin 9 Ağustos 1920 tarihli toplantısında Genel Kurul toplantısında okunmuştur. Mazbatada; bağımsız sancak olan yerlerin kısa zamanda her alanda daha ileri hale geldiği, zaten bütün livaların ileride bağımsız liva olmaları yönünde Hükümetin yaklaşımı dolayısıyla teklifin görüşülmeye değer bulunduğu belirtilmektedir. Bu mazbata ilgisi dolayısıyla Dâhiliye Encümenine havalesi kararlaştırılmıştır (TBMM.ZC., Devre: 1, c. 3, s. 139-140).

Dâhiliye Encümeninin de teklifi olumlu bulması üzerine her iki Encümenin mazbataları TBMM'nin 18 Ağustos 1920 tarihli toplantısında görüşülmeye başlanmıştır. Önce Lâyiha Encümenin mazbatası, ardından da Dâhiliye Encümeni Mazbatası okunmuştur. 15 Ağustos 1920 tarihli Dâhiliye Encümeni mazbatasında, "Bütün livaların müstakil kılındığına, Bayezit Livasının da istiklâline mâni bir sebep görülemediğine binaen Lâyiha Encümeninin mazbatası liva-yı mezkûrun da Erzurum'dan irtibatının fekkiyle istiklâlinin icra buyurulmasına karar" verildiği belirtilmiştir. Bazı mebusların yeni memur kadroları ihdas edilmesi gerektiği gerekçesiyle Muvazene-i Maliye (Bütçe) Encümenine gönderilmesine yönelik önerileri kabul görmemiştir. Teklif üzerinde söz isteyen fazla olmadığ 1 için uzun uzadıya müzakere edilmemiştir. Oturumu yöneten Reis-i Sâni Vehbi Bey (Konya); her iki encümenin de kabul ettiği teklifi, Genel Kurul da kabul ederse gereği için Hükümete tebliğ edileceğini söyleyerek mazbataları oylamaya sunmuştur. Yapılan oylamada mebusların mazbataları kabul etmesiyle Bayezit Livası bağımsız sancak haline getirilmiş oluyordu (18 Ağustos 1920). Bu kanun şeklinde olmayıp "Meclis Kararı" şeklinde yasalaşmıştır. Meclisin bu kararı üzerine konu İcra Vekilleri Heyeti'nin gündemine gelmiş ve Bayezit'ın müstakil sancak olarak idaresi kararlaştırılmıştır (19 Ağustos 1920) (TBMM.ZC., Devre: 1, c. 3, s. 311-312; BCA. Fon Kodu: 030.18.01.01, Yer No: 1.9.12; https://www.tbmm.gov.tr/tutanaklar/KANUNLAR_KARARLAR/kanuntbmmc001/karartbmmc 001/karartbmmc00100036.pdf (Erişim Tarihi: 24.12.2019)). Süleyman Sûdî Bey'in teklifinin TBMM'nde kabulü ile çeşitli değişikliklerle ${ }^{8}$ günümüzde adı "Ağrı" olan ilin kuruluşu gerçekleşmiş oluyordu.

Bayezit Mebusu Süleyman Sûdî Bey ve arkadaşlarının Meclise sundukları başka bir teklif; "Harcırahların Tenkisi" yani harcamaların kısıtlanmasıyla ilgilidir. Meclisin 24 Temmuz 1920 tarihli oturumunda toplantıyı yöneten Meclis Başkanı; Hükümetin de benimsediği bir konu olduğunu belirterek teklifin Lâyiha Encümenine gönderildiğini duyurmuştur (TBMM.ZC., Devre: 1, c. 2, s. 381). Teklif Encümende görüşülmüş ve o sırada aynı konuda Maliye Vekaleti'nin teklifi de Meclis gündeminde olduğu için Süleyman Sûdî Bey ve arkadaşlarının teklifinin nazar1 dikkate alınmasına gerek kalmadığına karar verilmiştir. Bu mazbatanın Genel Kurulda kabulü ile Süleyman Sûdî Bey ve arkadaşlarının teklifi kanunlaşamamıştır (18 Ağustos 1920) (TBMM.ZC., Devre: 1, c. 3, s. 302-303). Bu konuda sadece memurların harcırahları değil Meclis Başkanlık Divanı'nın kararının Genel Kurulda kabulü ile mebus harcırahlarının da \%40 kısılması ve bunun milli mücadeleye teberru (bağış) kabul edilmesi kararlaştırılmıştır (13 Eylül 1920) (TBMM.ZC., Devre: 1, c. 4, s. 109-112).

Süleyman Sûdî Bey Meclis Başkanlığına verdiği bir kanun teklifinde; "Mebusların Kendi Livalarında Vazife-i Tahkîki İcra Edebilmelerini” önermiştir. Meclisin 25 Haziran 1921 tarihli toplantısında bu teklif Lâyiha Encümenine havale edilmiş̧ir. Kanun teklifinin Lâyiha Encümenince de uygun buluna dair mazbata, Meclisin 7 Temmuz 1921 tarihli toplantısında

\footnotetext{
8 Trabzon-Tebriz ve (Erzurum)-Van-Bitlis yollarının üzerinde bulunması nedeniyle Bayezit Vilayeti'nin merkezi konumunda bulunması, merkez büyüklüğünün Bayezit'ın iki katı olması ve gelişmeye müsait olması nedeniyle Bayezit Vilayet merkezinin Bayezit'ten Karaköse Kazası merkezine ve Karaköse Kaza merkezinin de Bayezit'a nakledilmesi İcra Vekilleri Heyeti'nce kararlaştırılmıştır (24 Kasım 1926). BCA. Fon Kodu: 030.18.01.01, Yer No: 21.72.18. Merkezi Karaköse Kazası olan Bayezit Vilayeti'nin adının “Ağrı", merkezi Bayezit olan Karaköse Kazası adının da "Doğu Bayezit” çevrilmesi Bakanlar Kurulunca kararlaştırılmıştır (4.5.1935). BCA. Fon Kodu: 030.18.01.02, Yer No: 54.33.16. Ağrı Vilayeti'ne bağlı DoğuBayezit kaza merkezinin yalçın kayalı iki dağ sırtlarında bulunması nedeniyle gerek o günkü sosyal hayatın gelişmesi ve gerekse sıhhi şartların gerçekleştirilmesine uygun olmadığı için gelişmeye müsait bulunan eski merkeze $4,5 \mathrm{~km}$. uzaklıktaki İran ve Rusya Transit yolu üzerindeki istasyon bölgesine taşınmasının uygun olacağı Üçüncü Umumi Müfettişlik, Ağrı Vilayet Meclisi ve İdare Heyetince teklif edilmiştir. Bu teklifin İçişleri Bakanlığı'nca da uygun bulunması üzerine hazırlanan üçlü kararname Cumhurbaşkanı M. Kemal Atatürk tarafında 30 Eylül 1936 tarihinde tasdik edilmiştir. BCA. Fon Kodu: 030.11.01.00, Yer No: 107.35.12.
} 
okunmuştur. Oturumu yöneten Meclis İkinci Reis Vekili Faik Bey, bu teklifin mebusların yetkilerinin arttırılmasını içerdiğini belirterek, bu durumun Anayasayı ilgilendirdiğini ve bu nedenle teklifin Teşkilat-1 Esasiye Encümenine havale edildiğini söylemiştir (TBMM.ZC., Devre: 1 , c. 11 , s. $39,150-151)$.

Süleyman Sûdî Bey'in ilgilendiği konulardan birisi de; Vilayat-1 Şarkiye mültecilerinin durumlarıyla ilgilidir. I. Dünya Savaşı sırasında Doğu vilayetlerin Anadolu içlerine göç etmek zorunda kalan muhacirlerin bir kısmı kendi imkânlarıyla memleketlerine dönerken, önemli bir kısmı göç ettikleri yerlerde fakr-u zaruret içinde hayatlarını devam ettirmekteydiler. Bu mültecilerin memleketlerine sevki için İcra Vekilleri Heyetince Erzurum Mebusu Salih Efendi ile Bayezit Mebusu Süleyman Sûdî Bey’den oluşan bir komisyon oluşturularak, en çok mültecinin bulunduğu Konya ve Ereğli'ye gönderilmiştir. Her mebusa dört yüzer lira harcırah verilmiştir (2 Ocak 1921) (BCA. Fon Kodu: 030.18.01.01, Yer No: 2.26.12).

Binlerce mültecinin sevki o günkü şartlarda tam anlamıyla bir düzen içerisinde gerçekleştirilemediği için bazı mebuslar bu konuyu verdikleri önergelerle Meclis gündemine taşımışlardır. Erzurum Mebusu Mustafa Durak Bey ve arkadaşlarının verdikleri takrirlerin yanında Süleyman Sûdî Bey de konuyla ilgili olarak İcra Vekilleri Riyaseti, Maliye ve Sihhat ve Muavenet-i İçtimaiye Vekaletlerince cevaplandırılmak üzere bir sual takriri (soru önergesi) vermiştir. Bu takrirler TBMM'nin 20 Haziran 1921 tarihli toplantısında okunmuş, mebusların müstaceliyet talepleri üzerine de o günkü Meclis gündemine alınmıştır. Sual takririnde Doğu vilayetlerinde Türk nüfusun muhafazasının önemine değinen Süleyman Sûdî Bey; I. Dünya Savaşı sırasında bölge halkının büyük çoğunluğunun hayatını kaybetmesi veya göç etmesi nedeniyle nüfusun oldukça azaldığını (örneğin; Bayezit Sancağı'nın nüfusu savaştan önce 250 bin civarında iken 25 binlere kadar düşmüştür), göç edenlerin gittikleri yerlerde ortakçılık, yarıcılık veya amelelik vs. ile geçinmeye çalıştıklarını ifade etmiştir. Zor şartlarda hayatlarını devam ettirmeye çalışan bu muhacirlerin bir an önce memleketlerine dönebilmeleri içini Hükümetin yardımına ihtiyaç duyulduğunu belirten Süleyman Sûdî Bey, daha önce muhacirlerin sevki için İcra Vekilleri Heyetince bir karar verildiğini, ancak uygulanamadığını kaydetmiş ve konuyla ilgili olarak İcra Vekilleri Heyeti Reisi Fevzi Paşa ile Maliye ve Sihhiye Vekilleri tarafından açıklama yapılmasını talep etmiştir. Diğer takrirlerle birlikte bu sual takririyle ilgili açıklama yapmak üzere kürsüye gelen Sıhhat ve İçmai Muavenet Vekili Bayezit Mebusu Dr. Refik (Saydam) Bey; Muhacirin Müdüriyetinin kısa bir süre önce Dâhiliye Vekaletinden ayrilarak kendi bakanlığına bağlandığını, bütçede muhacirlerin iaşe ve sevkiyatı için yaklaşık 500 bin lira ayrıldığını ve bu paranın da muhacirlerin ihtiyaçlarını karşılamaya yetmediğini anlatmıştır. Ülkedeki muhacir ve mültecilerin tam sayısının bile tespit edilemediğini ifade eden Refik Bey, sadece şark vilayetlerinden iç bölgelere göç etmiş olanların sayısının yaklaşık 60-70 bin civarında bulunduğu ve Hükümetin bu ailelerin ihtiyaçlarının karşılanmasına çalıştığını ifade etmiştir. Refik Bey ayrıca; Geçici bütçede Muhacirin için ayrılmış olan 377 bin liralık ödeneğin verilmesi hususunda Meclis kararı alınırsa bu muhacirlerin memleketlerine gönderilmesinin mümkün olacağını kaydetmiştir. Yapılan tartışmalardan sonra geçici bütçe görüşmelerinin hızlandırılması amaciyla takrirlerin Muvazene-i Maliye Encümenine (Bütçe Komisyonu) havalesi kabul edilmiştir (TBMM.ZC., Devre: 1, c. 10, s. 455).

Vilayet-i Şarkiye muhacirlerinin sorunlarının takipçisi olmaya devam eden Süleyman Sûdî Bey, 17 Haziran 1922 tarihinde TBMM'ne verdiği temenni takririnde "Vilayât-1 Şarkiye mültecilerine verilecek meccani kereste hakkındaki kanun lâyihasının müstacelen görüşülmesini" istemiştir. Bu kanunun acilen görüşülmek üzere Meclis gündemine alınması oylamaya sunulmuş ve kabul edilmiştir. Uzun tartışmalardan sonra, bu konudaki kanun teklifi kabul edilerek çeşitli sebeplerle (savaş, isyan, doğal afet vb.) mağdur olan halkın kullanımı için ücretsiz kereste verilmesine dair kanun kabul edilmiştir (17 Haziran 1922) (TBMM.ZC., Devre: 1, c. 20, s. 420425 ; 455, 463-484).

Vilayat-1 Şarkiye muhacirlerinin yerlerine dönmeleri ve meskenlerini tamir ve inşası için ayrı bir kanun daha çıkarılarak 150 bin lira ödenek ayrılmıştır (3 Nisan 1923) 
(https://www.tbmm.gov.tr/tutanaklar/KANUNLAR_KARARLAR/kanuntbmmc001/kanuntbm mc001 /kanuntbmmc00100319.pdf). Kanun çıkmasına rağmen halkın mesken yapması için ücretsiz kereste dağıtılması işinde aksamalar yaşanması nedeniyle Süleyman Sûdî Bey, 15 Eylül 1923 tarihinde konuyu tekrar Meclis gündemine getirmiştir. Muhtaç halka tohumluk buğday dağıtılmasıyla ilgili kanunun görüşülmesi sırasında söz alan Süleyman Sûdî Bey; Sarıkamış orman memurlarının gerekli kolaylığı göstermemeleri nedeniyle halkın meskenlerini yapamadığını, kışın yaklaşmasıyla halkın mağduriyetinin artacağını vurgulamıştır (TBMM.ZC., Devre: 2, c. 2, s. 125).

Süleyman Sûdî Bey, Suşehri Jandarma Bölük Kumandanı hakkında Dâhiliye Vekilinin cevaplandırması isteğiyle 10 Mayıs 1922 tarihli bir soru önergesi vermiştir. Bu önerge ve Dahiliye Vekili Ali Fethi Bey'in yazılı cevabı Meclisin 29 Haziran 1922 tarihli toplantısında okunmuştur. Süleyman Sûdî Bey; seçim bölgesi olan Bayezit'ten Ankara'ya dönerken yol güzergahı olduğun için uğradığı Suşehri'nde duyduğu ve bir olayı Meclis gündemine taşımıştır. Bu önergede; Koyulhisar Jandarma Bölük Kumandanı, verdiği kanunsuz emirler ve uygunsuz hareketleri dolayısıyla Suşehri'ne tayin edildiği, burada da aynı kanunsuz hareketlere devam ettiği, haksız yere bir kişinin ölümüne ve eşyasının yağmalanmasına neden olduğu belirtilmekte ve bu kişinin terfi ettirilerek Karahisar-1 Şarkî Jandarma Tabur Kumandanlığına tayin edilmesi hakkında açıklama istenilmiştir. Dahiliye Vekili Ali Fethi bu önergeye yazılı cevabında; Karahisar-1 Şarkî Taburu Merkez Bölük Kumandanı Yüzbaşı Subhi'nin eşkıya Aynacıoğlu Bekir'i takip ve bu kişinin evinin aranması sırasında ailesinden 100 altın alması ve verdiği emirle Suşehirli Şerif' in katledilmesinden dolayı görevden alındığı ve mahkemeye sevk edildiğini belirmiştir. Dahiliye Vekili ayrıca, bu kişinin terfi ettirilerek Tabur Kumandanı olduğu bilgisinin yanlış olduğunu vurgulamıştır (TBMM.ZC., Devre: 1, c. 20, s. 20, 163-164).

Süleyman Sûdî Bey, devam eden rahatsızlığı nedeniyle verilen doktor raporuna istinaden Meclis faaliyetlerine katılamayacağı için izin talebinde bulunmuştur. TBMM Başkanlık Divanı'nın 11 Ekim 1922 tarihli toplantısında bu talep uygun bulunarak 6 ay izin verilmesi kararlaştırılmış ve bu karar Meclis Genel Kurulu'nda da kabul edilerek Süleyman Sûdî Bey'e altı ay izin verilmiştir (12 Ekim 1922) (TBMM.ZC., Devre: 1, c. 23, s. 365).

\section{Süleyman Sûdî Bey’in II. TBMM Dönemindeki Faaliyetleri}

II. TBMM için yapılan mebus seçiminde 186 oyla tekrar Bayezit Mebusu seçilen Süleyman Sûdî Bey'in 4 Ağustos 1923 tarihli mazbatas1 Meclis Genel Kurulunca 19 Ağustos 1923 tarihinde tasdik edilmiş ve 1 Eylül 1923 tarihinde Meclise katılmıştır (https://www.tbmm.gov.tr/eyayin/GAZETELER/WEB/MAZBATALAR/TBMM/d02/HT_47_1 _2.pdf).

Süleyman Sûdî Bey'in II. TBMM döneminde verdiği tek kanun teklifi Karaköse'de bir idadi mektebi açılmasına dairdir. Süleyman Sûdî Bey'in Bayezit'a bağlı Karaköse (Ağrı) Kazası merkezinde Resicumhur Gazi Mustafa Kemal Paşa adına bir idadi mektebi açılmasına dair kanun teklifi Meclisin 7 Ocak 1924 tarihli toplantısında incelenmek üzere Lâyiha Encümenine gönderilmiştir (TBMM.ZC., Devre: 2, c. 4, s. 700). Lâyiha Encümenince uygun bulunan teklif daha sonra ilgisi dolayısıyla Maarif ve Muvazene-i Maliye (Bütçe) Encümenlerine gönderilmiştir (14 Ocak 1924) (TBMM.ZC., Devre: 2, c. 5, s. 85). Maarif Encümeninde Maarif Vekili İsmail Safa Bey'in de katıldığı toplantıda bu teklif müzakere edilmiştir. Yapılan müzakerede; Karaköse kaza merkezinde bir idadi mektebine talebe yetiştirecek kadar iptidai mektep bulunmadığ için bu mektebin yapılmasının uygun olmayacağı kanaatine varılmıştır. Ancak bu görüşmelerde İsmail Safa Bey'in, 1924 yılında doğu illerinde yapılacak 10 tane leylî iptidaî mektepten (yatılı ilkokul) birisinin Karaköse'de yapılmasına dair söz verdiği Encümen mazbatasına yazılmıştır. Bu Encümen mazbatası TBMM'nin 9 Şubat 1924 tarihli toplantısında kabul edilmiştir (TBMM.ZC., Devre: 2, c. 6, s. 121-122). Böylece Süleyman Sûdî Bey'in Karaköse kaza merkezinde bir idadi (lise) açılması girişimi (Gazi Mustafa Kemal Paşa'nın isminin verilmesi önerisine rağmen) 
idadiye talebe yetiştirecek iptidai mektep bulunmadığı, dolayısıyla okulun öğrencisiz kalacağı gerekçesiyle reddedilmiş oluyordu.

Süleyman Sûdî Bey, Karaköse Ahz-1 Asker (Asker Alma) Şube Reisi Binbaşı Hamdi Bey'in uygunsuz karar ve hareketlerine dair 24 Eylül 1923 tarihinde Meclise bir takrir vermiştir. Aynı mealde Karaköse Belediye Riyaseti'nden TBMM Arzuhal Encümenine (Dilekçe Komisyonu) bir arzuhal de gönderilmiştir. Bu takrir ve arzuhal Meclis Başkanlığınca İcra Vekilleri Heyeti'ne havale edilmiştir (26 Eylül 1923). Meclis Başkanlığının bu yazıları ilgisi dolayısıyla 29 Eylül 1923 tarihinde Müdafaa-1 Milliye Vekâleti'ne sevk edilmiştir'. Bu takrire ne cevap verildiği veya bir işlem yapılıp yapılmadığı zabıt ceridelerinden ve arşiv belgelerinden tespit edilememektedir.

İstiklâl Harbi'nde malül olan komutan ve subaylara ikramiye verilmesine dair kanun teklifinin TBMM'nde görüşülmesi sırasında bir önerge veren Süleyman Sûdî Bey; TBMM'nin şanına yakışacak bu ikramiye verilmesini desteklemekle birlikte, bu uygulamanın genişletilerek ikramiyenin bu savaşlarda şehit olanların evlatlarına da verilmesini talep etmiştir. Yapılan görüşmelerde bu öneri kabul görmemiş ve ikramiye malül olanlara verilmiştir (7 Ocak 1924) (TBMM.ZC., Devre: 2, c. 4, s. 723-728).

21 Ekim 1923 tarihinde TBMM Riyaseti'ne yazılı soru önergesi veren Süleyman Sûdî Bey; Karaköse Kazası Jandarma Bölük Kumandanı Yüzbaşı Hikmet Efendi'nin defalarca kanuna aykırı uygulama ve hareketleri cereyan ettiği halde Bayezit Valisi Kâmil Bey'in bu kişi hakkında soruşturma açtırmayarak evrakı beklettiğini iddia etmiş ve Dâhiliye Vekilinden açıklama istemiştir. Soru önergesini yazılı olarak cevaplandıran Dâhiliye Vekili Ferit Bey; Yüzbaşı Hikmet Efendi'nin "cinayet suçlaması" nedeniyle 30 Ağustos 1923 tarihinde Bayezit Vilayeti Memurin Encümeni'nce hakkında soruşturma açılmasına karar verildiğini belirtmiştir. Aynı konuda 17 kişinin daha haklarında soruşturma yürütüldüğünü ifade eden Ferit Bey; bu kişilerin ikametgâhlarının Kars ve Kâğızman gibi uzak yerlerde bulunması ve buralara yazılan yazılara cevap alınamaması nedeniyle soruşturmanın tamamlanamadığını, Yüzbaşı Hikmet Efendi'nin ise 25 Şubat 1923 tarihinde açığa alındığını ve soruşturma tamamlandığında kumandan hakkındaki evrakın TBMM Memurin Muhakemat Encümeni'ne takdim edileceğini vurgulamıştır (24 Kasım 1923) (TBMM.ZC., Devre: 2, c. 3, s. 591).

Süleyman Sûdî Bey; "Beygi Aşireti Reisi Kaymakam Abdülmecit Bey hakkında sâdır olan tevkif müzekkeresinin infaz edilmemesi (çıkarılan yakalama emrinin uygulanmaması)" ve "Eleşkirt Kazası Halebî Karyesi'nde oturan Osman Ağazâde Mustafa Ağa'nın evine taarruz eden eşkıya hakkında" iki sual takriri (soru önergesi) vermiştir. Bu takrirlerde; bilinen eşkıyaların adamların 15 civarında silahı kişinin Mustafa Ağa'nın çiftliğine saldırarak yaktı̆̆ı, oğlunu katlettiği ve 80 civarında koyununu gasp ettiği belirtildikten sonra aylar geçmesine rağmen eşkıyaların yakalanamadığı vurgulanmaktadır. TBMM'nin 12 Aralık 1923 tarihli oturumunda bu takrirler cevaplandırılmak üzere Dâhiliye Vekâletine havale edilmiştir (TBMM.ZC., Devre: 2, c. 4, s. 165; BCA. Fon Kodu: 030.10.00.00, Yer No: 6.34.4). Bu takrirlere cevap verilip verilmediği TBMM zabıt ceridelerinden anlaşılamamaktadır. Süleyman Sûdî Be, bu takrirlere cevap alamamış olacak ki; Beygi Aşireti reislerinden Abdülmecit ve avenesi hakkında 19 Aralık 1923 tarihinde şifahi cevap verilmek üzere yeni bir takrir daha vermiş ve bu takrir de Dâhiliye Vekâletine tebliğ edilmiştir (TBMM.ZC., Devre: 2, c. 4, s. 295-296).

Süleyman Sûdî Bey; Şehit Kaymakam Abdülkadir Bey’in yetimleri ve Eleşkirt kazasından şehit Mülâzım Cemal Efendi'nin evlatları ile mütekait Mülâzım Cuma Efendi’ye Karaköse Mal Müdürlüğü tarafindan ödenmesi gereken 1921-1922 yıllarına ait birikmiş maaşların ödenmemesiyle ilgili sözlü soru önergesi vermiştir. Bu soru önergesi TBMM'nin 16 Ocak 1924 tarihli oturumunda Maliye Vekili Abdülhâlık Bey tarafından cevaplandırılmıştır. Soru

\footnotetext{
${ }^{9}$ TBMM.ZC., Devre: 2, c. 2, s. 288-289; BCA. Fon Kodu: 030.10.00.00, Yer No: 6.31.21. Hamdi Bey'in sû-i hâl ve mu'âmelesi olarak şu hususlar dile getirilmektedir: Ticaretle uğraşmak, oğlu aracılı̆̆ılla askeri ve sivil kurumların elinde bulunan emvâl-i metrukeden çok sayıda top mermisinin ticaretini yapmak, kışla ve camiye su sağlayan hayrat hakkında olumsuz ifadeler kullanmak.
} 
önergesinde belirtilen hususların doğru olduğunu belirten Abdülhâlık Bey; Abdülkadir Bey'in yetimlerinin başka yerlere göç edip geri döndükleri için evrakın gecikmesi nedeniyle maaşlarını alamadıklarını, Cuma Efendi'nin emeklilik evrakının ödeme emrinin geç gönderilmesi nedeniyle maaşların ödenemediğini ifade etmiştir. Cemal Efendi'nin yetimlerinin de Bayezit'te değil de Sivas'ta olmaları ve oradaki yetkililerin bu çocukların maaşlarını bilmedikleri için ödeme yapılmadığını kaydeden Abdülhâlık Bey; bu kişilerle ilgili evrakın en kısa zamanda gönderileceği ve gerekli ödemelerin yapılacağını söylemiştir (TBMM.ZC., Devre: 2, c. 5, s. 141).

Süleyman Sûdî Bey; firara sebebiyet vermekten mahkum edilen Karaköse kazası ahalisinden Karslı Mahmut Ağazâde Haşim Efendi'nin Af Kanunu'ndan yararlanamamasına dair Meclis Başkanlığı'na bir temenni takriri vermiştir. TBMM'nin 22 Kasım 1924 tarihli toplantısında okunan takrir, Süleyman Sûdî Bey'in de isteğiyle incelenmek üzere Adliye Encümeni'ne havale edilmiştir (TBMM.ZC., Devre: 2, c. 10, s. 358).

Ülkenin genel sorunlarından ziyade yerel halkın sorunlarının takipçisi olan ve o konuları Meclis gündemine taşıyan Süleyman Sûdî Bey, Ziraat Bankası'nın 1923 yılı Bütçesi görüşülürken söz alarak, Vilayat-1 Şarkiyede Ruslardan kalan tarım makinalarının halka dağıtılmasını istemiştir. Süleyman Sûdî Bey konuşmasının devamında işgal sırasında batı bölgelerine göç edip işgalden sonra memleketlerine geri dönen halkın Ziraat Bankası'na olan borçlarını ödeyecek durumlarının bulunmadığını ifade etmiştir. Bu konularla ilgili olarak açıklama yapan İktisat Vekili Hasan Bey; Ruslardan kalan tarım makinalarının Ziraat Bankası tarafindan askeriyeden alınıp halkın istifadesine sunulduğunu, borçların ödenmesi konusunun çözümü için Meclisten bir kanun çıkarılması gerektiğini, aksi takdirde borçların ödenememesinin durumunda Bankası'nın sermayesinin eriyip gitmesine neden olacağını ifade etmiştir (TBMM.ZC., Devre: 2, c. 3, s. 583).

Ağnam Resmi için hayvanları sayımı ile ilgili kanun görüşülürken söz alan Süleyman Sûdî Bey, İran'dan Trabzon limanına ticari eşya taşıyan develerin bu Ağnam Resminden muaf tutulmasının ticaretin gelişmesi açısından önemli olduğunu vurgulamıştır. İktisat Vekili Hasan Bey'in de desteklemesi üzerine Süleyman Sûdî Bey, bu konuda kanuna bir madde eklenmesine dair teklif vermiş̧tir. Encümenin de olumlu görüşü üzerine "Sayım Kanunu"na 20. Madde olarak bu muafiyet eklenmiştir (TBMM.ZC., Devre: 2, c. 5, s. 660, 665, 702; https://www.tbmm.gov.tr/tutanaklar/KANUNLAR_KARARLAR/kanuntbmmc002/ kanuntbmm c002/kanuntbmmc00200410.pdf).

\section{Sonuç}

Bayezit'in köklü ailelerinden birine mensup olan Süleyman Sûdî Bey, ilk ve orta öğrenimini memleketinde yapmıştır. İbtidai ve rüşdiye mektepleri yanında medrese eğitimi almıştır. Uzun süre Bayezit ve yakın kaza ve sancaklarda mahkeme kâtipliklerinde bulunmuştur. Bu görevleri sırasında hakkındaki iddialar/şikâyetler nedeniyle çeşitli defalar soruşturma geçirmiş ve yargılanmıştır.

II. Meşrutiyet'in ilanından sonra Bayezit Mebusu olarak Meclis-i Mebusan'da görev yapan Süleyman Sûdî Bey, vatandaşların hak ve özgürlüklerinin korunması konusunda mensubu bulunduğu İttihat ve Terakkî Fırkası yönetimi ile fikir ayrılıkları yaşamış ve bu firkadan istifa ederek Ahalî Fırkası kurucuları arasında yer almıştır.

Kanun-1 Esasi'de güvence altına alınan "haberleşmenin gizliliği" hakkı kapsamında mektupların açılmaması gerekirken, Süleyman Sûdî Bey'in kişisel mektuplarının Erzurum Valisi Celal Bey tarafından açılmasıyla ilgili tartışma Meclis-i Mebusan gündemine gelmiştir. Uzun tartışmalara ve Dâhiliye Nâzırı Mehmet Talât Bey hakkında güven oylamasına gidilmesine rağmen mektupların açılmasıyla ilgili olarak Süleyman Sûdî Bey; mektuplarının Vali tarafından postahaneden alınarak açıldığı iddiasını ispat ve konu ile ilgili bir cezalandırma yönünde bir sonuç elde edememiş ve konu kapanmak durumunda kalmıştır.

Süleyman Sûdî Bey ve birlikte hareket eden mebuslar, İttihat ve Terakki Cemiyeti ile Mecliste oluşturulan İttihat ve Terakki Fırkası'nı farklı kurumsal yapı olarak değerlendirmişler 
ve Meşrutiyetin İlanını sağlayan İTC'ne bağlı kalmakla birlikte, o cemiyetin Meclisteki temsilcisi olan ITTF'ndan istifa etmişlerdir. II. Meşrutiyetin başlangıcında tam olmasa da iktidarı temsil eden İTF'nın da bütün kararlarına muhalefet etmeyen Gümülcineli İsmail Hakkı ve beraberindekiler, Mecliste parti grubu şeklinde disiplin içinde hareket edilmesi yönündeki eğilime karşı akıl ve vicdanlarına uymayan konularda İTF'ndan ayrı hareket edebilmeyi tercih etmişlerdir. Yani her konuda firka yönetimine tam itaat ilkesine karşı gelmekle birlikte iktidarı temsil eden İTF'nın bütün politikalarına körü körüne muhalefet etmeye de taraftar değildirler. 1914 seçimlerinde seçilememesinin sebeplerinden birisi bu olabilir.

Milli Mücadele yıllarında ve sonrasında TBMM'nde Bayezit Mebusu olarak görev yapan Süleyman Sûdî Bey, siyasi faaliyet olarak büyük ölçüde kendi seçim bölgesini ilgilendiren konuların takipçisi olmuş ve bu sorunların çözümü için çaba harcamıştır. Bazılarında (Bayezit'in müstakil sancak olması, vilayeti şarkiye mültecilerinin durumu vs.) başarılı olsa da bazı konularda (kendi mektuplarının Vali tarafından açılması, Gazi Mustafa Kemal adına idadi açılması gibi) istediği sonuçları alamamıştır. Süleyman Sûdî Bey'in kendi seçim bölgesine en önemli ve unutulmayacak hizmeti daha önce defalarca girişimde bulunulmasına rağmen gerçekleşemeyen Bayezit'in müstakil sancak olması yönündeki öncülüğüdür. Bugünkü Ağrı İli'nin kurulmasının önemli bir aşaması onun ve onu destekleyen mebusların gayretleriyle sağlanabilmiştir.

\section{Kaynakça}

Atatürk, K. (1994). Nutuk 1919-1927, (Yay. Haz: Prof. Dr. Zeynep Korkmaz), Atatürk Araştırma Merkezi Yay, Ankara.

\section{Cumhurbaşkanlığ Cumhuriyet Arşivi (BCA)}

Cumhurbaşkanlığı Osmanlı Arşivi (BOA)

Çankaya, M. A. (1968-1969). Son Asır Türk Târihinin Önemli Olaylart ile Birlikte Yeni Mülkiye Târihi ve Mülkiyeliler, c. 2, Mars Matbaası, Ankara.

Çoker, F. vd. (1995). Türk Parlamento Tarihi Milli Mücadele ve TBMM I. Dönem 1919-1923, c. III, (Yay.Haz: Fahri Çoker ve Türk Parlamento Tarihi Hazırlama Grubu), TBMM Yay, Ankara.

Düstûr, Birinci Tertip, c. 4, Mahmud Bey Matbaası, İstanbul, 1299.

Güneş, İ. vd. (1998). Türk parlamento tarihi meşrutiyete geçiş süreci I. ve II. meşrutiyet, c. II, (Yay.Haz: Prof. Dr. İhsan Güneş ve Türk Parlamento Tarihi Hazırlama Grubu), TBMM Yay, Ankara.

http://tbmm.chp.org.tr/milletvekiliDetay.aspx ?ID=5667 (Erişim Tarihi: 09.12.2019).

http://tbmm.chp.org.tr/milletvekiliDetay.aspx?ID=5667 (Erişim Tarihi: 09.12.2019)

https://www.tbmm.gov.tr/eyayin/GAZETELER/WEB/MAZBATALAR/TBMM/d0

_47_1_2.pdf (Erişim Tarihi: 9.12.2019).

https://www.tbmm.gov.tr/eyayin/GAZETELER/WEB/MAZBATALAR/TBMM/d01/ SM_47_1_1.pdf (Erişim Tarihi: 09.12.2019).

https://www.tbmm.gov.tr/eyayin/GAZETELER/WEB/MAZBATALAR/TBMM/d02/ HT_47_1_2.pdf (Erişim Tarihi: 9.12.2019)

https://www.tbmm.gov.tr/eyayin/GAZETELER/WEB/MAZBATALAR/TBMM/d02/ HT_47_1_2.pdf (Erişim Tarihi: 9.12.2019).

https://www.tbmm.gov.tr/tutanaklar/KANUNLAR_KARARLAR/kanuntbmmc001/ karartbmmc001/ karartbmmc00100036.pdf (Erişim Tarihi: 24.12.2019). 
https://www.tbmm.gov.tr/tutanaklar/KANUNLAR_KARARLAR/kanuntbmmc001/ kanuntbmmc001/kanuntbmmc00100319.pdf ( Erişim Tarihi: 29.12.2019)

https://www.tbmm.gov.tr/tutanaklar/KANUNLAR_KARARLAR/kanuntbmmc002/ kanuntbmmc002/ kanuntbmmc00200410.pdf (Erişim Tarihi: 30.12.2019)

Meclis-i Mebusan Zabit Ceridesi.

Meclis-i Umumi Zabıt Cerideleri, Devre: 1, İçtima Senesi: 1, İn'ikâd: 3, c. 1, s. 32.

Resmi Gazete.

Süleyman Sûdî, "Fırkalar Dolayısıyla”, Yeni Gazete, No: 549 (22 Şubat 1325/7 Mart 1910), s. 2.

Tercüman-ı Hakîkat

Tozlu, S. (1997). Trabzon-Erzurum-Bayezit Yolu (1850-1900), (Yayınlanmamış doktora tezi), Atatürk Üniversitesi Sosyal Bilimler Enstitüsü, Erzurum.

Tunaya, T.Z. (1988). Türkiye'de Siyasal Partiler, c. 1, Hürriyet Vakfi Yay., İstanbul,

Türkiye Büyük Millet Meclisi Zabıt Ceridesi.

Yıldırım, M. (2018). II. Meşrutiyet Dönemi’nde Bayezit Sancă̆ l (1908-1918), (Yayınlanmamış yüksek lisans tezi), Ağrı İbrahim Çeçen Üniversitesi, Ağrı.

\section{ETIKK ve BİLIMSEL İLKELER SORUMLULUK BEYANI}

$\mathrm{Bu}$ çalışmanın tüm hazırlanma süreçlerinde etik kurallara ve bilimsel atıf gösterme ilkelerine riayet edildiğini yazar(lar) beyan eder. Aksi bir durumun tespiti halinde Afyon Kocatepe Üniversitesi Sosyal Bilimler Dergisi'nin hiçbir sorumluluğu olmayıp, tüm sorumluluk makale yazarlarına aittir. 